\title{
Review \\ The Role of BDNF in Experimental and Clinical Traumatic Brain Injury
}

\author{
David Gustafsson ${ }^{1}{ }^{\circledR}$, Andrea Klang ${ }^{2}$, Sebastian Thams ${ }^{3}$ and Elham Rostami ${ }^{1,4, *}$ \\ 1 Section of Neurosurgery, Department of Neuroscience, Uppsala University, 75124 Uppsala, Sweden; \\ dfsgustafsson@gmail.com \\ 2 Department of Clinical Neuroscience, Rehabilitation Medicine, Uppsala University, 75124 Uppsala, Sweden; \\ andrea.klang@akademiska.se \\ 3 Department of Clinical Neuroscience, Karolinska Institute, 17177 Stockholm, Sweden; sebastian.thams@ki.se \\ 4 Department of Neuroscience, Karolinska Institute, 17177 Stockholm, Sweden \\ * Correspondence: elham.rostami@neuro.uu.se
}

Citation: Gustafsson, D.; Klang, A.; Thams, S.; Rostami, E. The Role of BDNF in Experimental and Clinical Traumatic Brain Injury. Int. J. Mol. Sci. 2021, 22, 3582. https://doi.org/ $10.3390 /$ ijms 22073582

Academic Editor: András Büki

Received: 25 February 2021

Accepted: 26 March 2021

Published: 30 March 2021

Publisher's Note: MDPI stays neutral with regard to jurisdictional claims in published maps and institutional affiliations.

Copyright: () 2021 by the authors. Licensee MDPI, Basel, Switzerland. This article is an open access article distributed under the terms and conditions of the Creative Commons Attribution (CC BY) license (https:// creativecommons.org/licenses/by/ $4.0 /)$.
Abstract: Traumatic brain injury is one of the leading causes of mortality and morbidity in the world with no current pharmacological treatment. The role of BDNF in neural repair and regeneration is well established and has also been the focus of TBI research. Here, we review experimental animal models assessing BDNF expression following injury as well as clinical studies in humans including the role of BDNF polymorphism in TBI. There is a large heterogeneity in experimental setups and hence the results with different regional and temporal changes in BDNF expression. Several studies have also assessed different interventions to affect the BDNF expression following injury. Clinical studies highlight the importance of BDNF polymorphism in the outcome and indicate a protective role of BDNF polymorphism following injury. Considering the possibility of affecting the BDNF pathway with available substances, we discuss future studies using transgenic mice as well as iPSC in order to understand the underlying mechanism of BDNF polymorphism in TBI and develop a possible pharmacological treatment.

Keywords: BDNF; neurotrophins; neurotrophic factors; traumatic brain injury; neuroregeneration; neuroprotection; brain; neurons

\section{Introduction}

Traumatic brain injury (TBI) is the leading cause of death worldwide, and in young adults under 35 years of age, the death rate is 3.5 times that of cancer and heart disease combined [1]. TBI is a dynamic condition with an initial primary injury triggering secondary events that can progress over hours, months, and even years. These events can be harmful such as ischemia, energy failure and inflammation, or beneficial such as the increased expression of neurotrophins and growth factors that promote neuronal survival and plasticity.

Neurotrophins, in particular brain derived neurotrophic factor (BDNF), have been identified to play a prominent role in the cellular events that occur in restorative processes following TBI, such as neuronal survival, axonal sprouting, and synaptogenesis [2]. Due to the important role of BDNF, its impact has been widely investigated in experimental TBI models and human studies [3]. It has also been shown that BDNF polymorphism influence the outcome after TBI, but the underlying mechanism has not been fully understood. As we will explore in this article, there is also a discrepancy in the results from experimental models studying BDNF expression regarding time post-injury, anatomical localization, and outcome. In this review, we aim to cover the findings in experimental TBI investigating BDNF and human studies exploring the effect of BDNF polymorphism in order to identify key knowledge gaps to direct future studies. 


\subsection{Brain Derived Neurotrophic Factor (BDNF)}

BDNF is the most abundant neurotrophin in the brain [4,5], playing an important role in the survival, differentiation, synaptic plasticity, and axonal outgrowth of peripheral and central neurons throughout adulthood $[2,4,6]$. BDNF mediates its effect through the high affinity tyrosine kinase receptor (TrkB) [7]. An increased expression of TrkB mRNA has been detected in the site of injury following spinal cord injury and TBI [8,9]. BDNF also binds to a pan-neurotrophin receptor p75NTR, a member of the tumor necrosis factor receptor (TNFR) family [10]. The p75NTR receptor has been suggested to have a dual role both as a facilitator of Trk-mediated neuronal survival and as a regulator of neuronal cell death through the initiation of apoptosis. Accordingly, one of the drawbacks of treatments using BDNF analogs has been that they also affect p75NTR receptors mediating apoptosis. Thus, a TrkB selective drug or p75NTR inhibitor would be more beneficial.

\section{BDNF Val66met Polymorphism}

The BDNF single nucleotide polymorphism (SNP) in rs6265 produces a missense mutation, Val66Met (196G/A), which causes deficits in the activity-dependent secretion of BDNF [11]. The Val66Met mutation occurs in about $30 \%$ of the population in the US (met carriers/met+). When translated, the BDNF molecule contains three important domains: the signal peptide, the prodomain, and the functional BDNF molecule, all acting on different receptors. Mature BDNF binds to TrkB receptors and promotes long-term potentiation (LTP), cell survival, and dendrite formation; whereas proBDNF binds to p75NTR and activates long-term depression (LTD), apoptosis, and reduces dendritic complexity. This dual mechanism works antagonistically and regulates neuroplasticity. The Val66Met mutation results in accumulation of metBDNF in the soma while valBDNF accumulates in punctuate vesicles in dendrites. Neurons cannot secrete metBDNF in response to activity resulting in impaired plasticity in met carriers.

\section{BDNF Polymorphism in Human Studies}

The most studied polymorphism of BDNF in humans is rs6265 (Val66Met), in relation to normal cognitive function, effects on psychiatric, neurodegenerative and neuroinflammatory disease, and traumatic brain injury [11-15]. This has also been the case in TBI [16,17], although additional SNPs such as rs71244 [18,19], rs1519480, rs7124442 [20], and rs1153659 [21] have been identified to influence the outcome after traumatic brain injury. The SNP rs6265 of BDNF causes the substitution of valine to methionine and the prevalence of heterozygote or homozygote carriers of methionine is around $30 \%$ the population of the United States [22], but varies globally [23]. Most studies compare homozygote valine-carriers (Met-) to heterozygote and homozygote methionine-carriers $(\mathrm{Met}+)$. A minority of studies have three groups $[17,24,25]$, separating heterozygote met+ from homozygote met+.

Among healthy individuals (mean age $36 \mathrm{y}$ ), carriers of the met-allele had worse episodic memory measured with n-back working memory test, as well as abnormal hippocampal activity assessed by functional MRI (fMRI), compared to Met- [11]. Similar results have been shown in another study with healthy individuals (mean age $30 \mathrm{y}$ ), also measuring episodic memory and activity of the hippocampus with fMRI during the test [26]. The met-carriers had $25 \%$ less activation of hippocampal regions and poorer performance at recognizing "new" and "old" information. Interestingly, there are indications that being a met-carrier may have cognitive benefits when aging. The Scottish Mental Survey 1947 included genetic analysis and long-term follow up and showed that that met-carriers had better preserved non-verbal reasoning skills at older age (mean age 79) [15], indicating that met-carriers may conserve cognitive function better than met-, during aging. The benefits have also been shown in the risk of developing Alzheimer's disease among non-TBI individuals, where the risk was higher for val-homozygotes later in life but the reverse among younger subjects [14]. This is consistent with the theory of met+ having a positive impact on the preservation of cognitive function at older age. 


\subsection{BDNF Polymorphism and Outcome after Mild and Moderate TBI}

The effect of BDNFval66met polymorphism on the early cognitive outcome after mild TBI (mTBI) have been assessed in two different studies and shown a worse result for metcarriers. At a subacute follow up (one month) after mTBI, both the Met+ controls and the Met+ TBI-group had a slower reaction time in both simple reaction time (SRTRT—simple reaction time reaction time) and information processing speed (measured with Gordon Continuous Processing Test-CPT) compared to Met-patients and controls [17]. This correlates to another study where the participants were tested in five cognitive domains: attention, memory, language, visuospatial, and executive functions, immediately after recovery and at a six months follow up [27]. Overall, Met- had a better neurocognitive performance, without any significant difference between the two time points. However, met-carriers performed significantly worse at the memory test at six months, indicating a deterioration of some domain of cognitive function.

Nevertheless, in the follow up of military veterans after mTBI in the chronic phase (mean 4.5 years), evaluating memory and executive function, the Met+ group with TBI had better results than their corresponding control group, whereas the Met- had the opposite result [28]. This could indicate that presence of the Met+ SNP result in a lower baseline of cognitive function but offer a protective quality of cognition post TBI.

The risk for neurodegeneration after TBI has been discussed and evaluated in different studies [29]. Severe TBI has been associated with a higher risk for neurodegeneration but during the last decade this link has also been proposed for mild TBI [30,31]. To find early signs of dementia, the volume of Hippocampus was evaluated with MRI in individuals with history of mTBI compared to controls, in relation to several BDNF SNP's. Rs1153659 minor allele was correlated to a higher risk of reduced hippocampal volume after mTBI compared to controls but there was no difference for rs6265 [21].

In a study investigating the effect of headings in soccer players during six months on remyelination assessed by diffusion tensor imaging (DTI), it was shown that the metcarriers had significantly less remyelination compared to val-homozygot players [32]. This may explain part of the underlying pathophysiology in the poor functional outcome following repetitive $\mathrm{mTBI}$ in soccer players. There might be a gender difference as indicated by a Larson-Depuis et al. where female athletes with a history of concussion had a better olfactory function if they were met-carriers compared to val-homozygotes [25]. Olfactory function was proposed as a potential indicator of structural and functional injury after concussion, as well as a structure of the brain known to be able to regenerate and susceptible to BDNF.

Cognitive outcome after TBI is multifactorial. Age and gender affect the outcome $[18,19,33]$ and the severity and type of brain injury will affect cognition. Additionally, psychiatric factors can have consequences for cognitive function. Post-traumatic stress disorder (PTSD) has become increasingly discussed as a possible consequence to TBI [34], which in return can have an impact on cognitive function. One study reports of an increased prevalence of PTSD among Met+ patients with mTBI [24]. Another psychiatric factor that can interact with cognition is depression, which in return can be a consequence of TBI [35]. Met+ students reported a higher incidence of depressive symptoms after self-reported mTBI compared to Met- students with a history of mTBI [36,37]. The difference was more pronounced among female students.

The gender difference related to depressive and anxiety related symptoms was further addressed in a study that followed those symptoms in a group of patients one and six weeks post mTBI [36]. This study evaluates a different BDNF polymorphism and found that men with t-allele, a different polymorphism from val66met, had a higher risk for depression after six weeks, while this was not the case for women. Patients with a history of mild to moderate TBI and a diagnosed depression responded differently to Citalopram, depending on BDNF rs6265, where the best responders were val-homozygotes [38]. 


\subsection{BDNF Polymorphism and Outcome in Severe TBI}

Only one study could be identified that investigated the effects of BDNFval66met polymorphism on early recovery after severe TBI [39]. Bagnato et al. assessed the cognitive function of 53 patients in vegetative state following severe TBI using Rancho Levels of Cognitive Function Scale. The test was performed at 1-, 3-, 6-, and 12-months post injury and no difference could be detected between met-carriers compared to Met-.

There are a few studies on long term outcome following severe, penetrating brain injury in American Vietnam veterans were correlation of BDNF polymorphism and cognitive outcome has been studied $[16,20,40]$. The follow up of these studies are 40 years after the TB I. Two of these studied the impact of BDNF polymorphism on IQ and executive function in veterans with penetrating TBI in the prefrontal cortex (PFC). Both found preserved preserved cognitive function in met-carriers with TBI compared to non-met-carriers [16,40]. In the third study all penetrating injuries were included with no preference of PFC [20]. In this study no significant difference was found between the groups for SNP rs6265 but two other BDNF SNP's had significant effect on IQ, rs1519480 and rs7124442. This may indicate that there is a protective effect of BDNF polymorphism following injury and there might be a synergistic effect with different anatomical regions.

Three studies have used a gene risk score based on "risk" BDNF SNPs (rs6265 and rs $7124442)[18,19,33]$, adjusted for age, to assess global outcome and mortality after severe TBI. Two studies showed a lower mortality during the first year (8-365 d) after TBI among the younger population $(<45$ and $<48 \mathrm{y}$ ) with the low gene risk score (ie met- and rs7124442 t-homozygote), whilst the older population with low gene risk score had a higher mortality $[18,33]$. The third study had similar results where lower age had a higher rate of survival at six months with low gene risk score, though these results were to some extent influenced by levels of CSF cortisol as well [19].

\subsection{BDNF Levels in CSF and Plasma after TBI}

Three studies could be identified where BDNF levels were measured in plasma and/or CSF. Simon et al. analyzed the levels of BDNF in plasma at admission to the ICU, at mean $6.4 \mathrm{~h}$ post arrival to the hospital following severe TBI in 120 males (Glasgow Coma Scale (GCS) 3-8). There was no correlation between BDNF plasma levels and short-term fatal outcome (ICU mortality vs. ICU discharge) or between isolated brain injury versus multitrauma [41]. In 12 children with severe TBI levels of BDNF in CSF and plasma at 2 and $24 \mathrm{~h}$ post trauma, there was no correlation with the Glasgow Outcome Scale (GOS) at discharge [42], though there was a sharp peak of BDNF after head injury in all subjects. Another study including 315 patients with severe TBI showed a relation between BDNF levels in CSF in relation to levels of cortisol in CSF during the first week after the injury, and 6-month mortality [19]. Similarly, high CSF levels of BDNF daily sampled the first week post injury, were associated with an increased mortality (8-365 d post injury), whilst the acute mortality $(0-7 \mathrm{~d})$ was associated with low serum levels of BDNF [33].

The studies of the effect of BDNF val66met polymorphism vary in outcome measure, timing, and type of brain injury. Generally, the studies are small and most study population are smaller than 200 individuals. As a consequence, prospective studies are scarce and the results are heterogenous. The met/met prevalence in Caucasian population is low and therefore most studies group met-heterozygote and met-homozygote together for analysis.

\section{Experimental TBI}

In this section, we summarize the current knowledge of BDNF expression after traumatic brain injury (TBI) in different animal models, as well as the correlation between novel TBI treatment options and BDNF expression, and their effects on behavioral outcomes. In the section evaluating BDNF expression after TBI compared to sham, we chose to exclude studies which did not clearly state the location or time of BDNF analysis as well as those which did not report the data from sham animals. 


\subsection{Experimental Animal Models}

More than ten different trauma models have been used to study BDNF expression after TBI (Figure 1) and the most chosen method was controlled cortical impact (CCI), followed by fluid percussion injury (FPI) and weight drop models. No study specifically analyzed whether different trauma models differentially impact BDNF expression. The model chosen was determined by which type of trauma was sought to be emulated, e.g., blunt force or penetrating injury. We attempted to draw conclusions regarding the different trauma types impact on BDNF expression but there were conflicting results in the reviewed material. As an example, Colak et al. utilized a controlled cortical impact model whereas Wang et al. utilized a fluid percussion model and both found that trauma increased BDNF mRNA expression in the first day post injury (DPI) in cortical tissue ipsilateral to the injury [43,44]. On the other hand, Boone et al. also utilized a fluid percussion model and found decreased BDNF mRNA expression in the ipsilateral hippocampus after $20 \mathrm{~h}$ but not significantly affected expression at 4, 8, 16 and $24 \mathrm{~h}$ after injury [45]. In summary, to draw definitive conclusions there is need for a study that specifically analyze the different models' impact on BDNF expression.

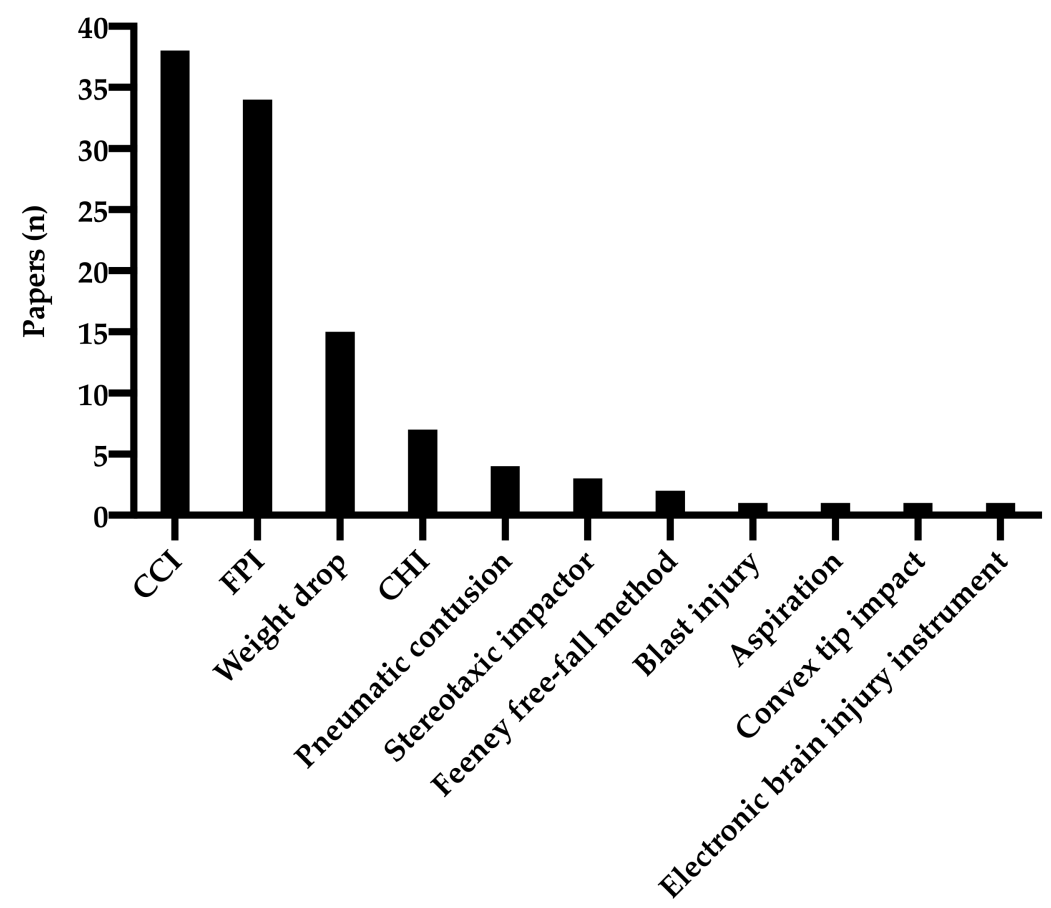

Figure 1. Trauma models in the reviewed studies.

\subsection{Anatomical Regions of BDNF Analysis}

In the reviewed material, the analyzed anatomical regions varied greatly. In order to compare and examine trends in the published data the anatomical regions were grouped together (Figure 2). Studies analyzing different regions, for example both ipsilateral and contralateral hippocampus (HC), were counted separately for each region analyzed. BDNF expression was most analyzed in the ipsilateral hippocampus and ipsilateral cortex, in 36 and 31 studies, respectively. In 7 studies the ipsilateral- and contralateral hippocampi were combined for biochemical examination and was labeled "bilateral $\mathrm{HC}^{\text {". }}$ 


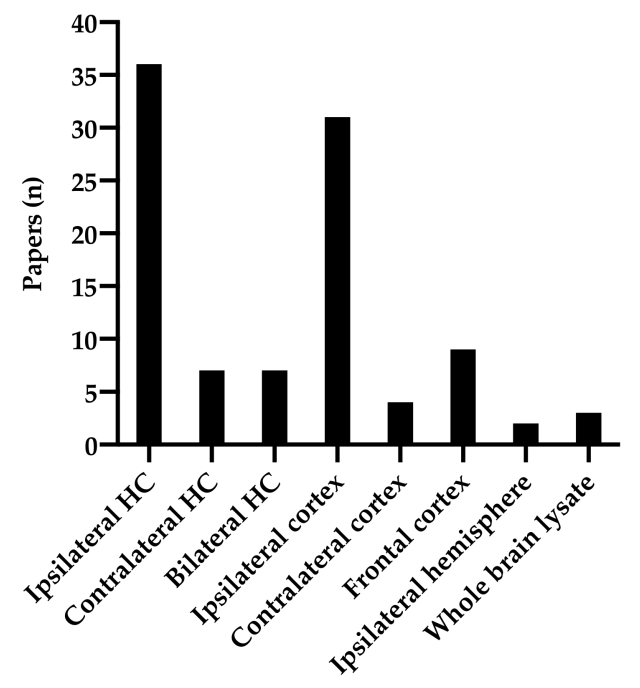

Figure 2. Anatomical regions analyzed in the reviewed material.

\subsection{Assessment of BDNF Expression}

Both the mRNA and protein expression of BDNF were assessed. The most common method for mRNA analysis were in situ hybridization and quantitative real-time polymerase chain reaction (qPCR). For BDNF protein quantification Western blot and enzyme linked immunosorbent assay (ELISA) were commonly used (Table A2). In most of the reviewed material BDNF protein expression was not explicitly specified into mature-, proor preBDNF. When not otherwise specified, we assumed that the study refers to total BDNF protein expression. Also, unless otherwise specified, the studies examined rat or mouse tissues.

\subsubsection{Hippocampus}

BDNF mRNA expression in the ipsilateral hippocampus was examined at 16 different timepoints and BDNF protein expression in the ipsilateral hippocampus was examined at 23 timepoints ( $2 \mathrm{~h}-56 \mathrm{~d}$ ) (Figure 3a). Three of the studies reported increased BNDF mRNA expression in the first 1 to $6 \mathrm{~h}$ after injury $[44,46,47]$, whereas one reported a decreased mRNA expression at $20 \mathrm{~h}$ after trauma in both TBI and sham groups [45]. At all other subsequent time points, BDNF mRNA expression in the ipsilateral hippocampus was reported to be decreased or not affected compared to the sham (Figure 3a) [9,47-52]. Interestingly, BDNF protein expression did not show any significantly increased expression in the first day after trauma and showed decreased or not altered expression in the following weeks (Figure 3b). One study reported a non-significantly affected expression in the hours after trauma but found increased protein expression at $26 \mathrm{~h}$ after injury [46]. BDNF protein expression in the ipsilateral hippocampus was repeatedly reported as non-significantly affected by trauma at $5 \mathrm{~h}$ after injury as well as 1, 7, 11, 15, 21, 26, and 37 DPI. However, several studies reported a decreased protein expression at $4,7,8,10,13,14$, and 28 DPI [53-69]. The expression data from each date was usually from a single study per date, as well as almost exclusively from CCI or FPI trauma. There was no clear difference between trauma groups from the available data. 


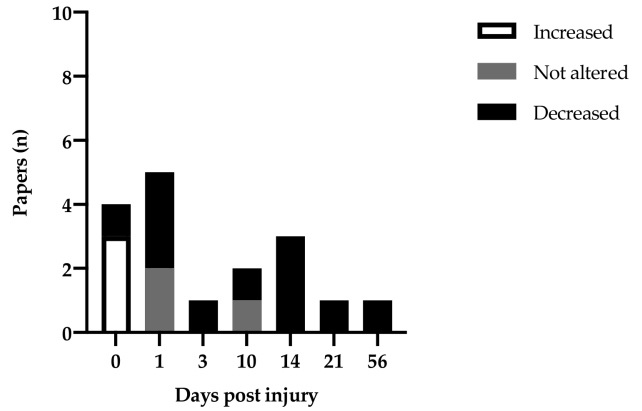

(a)

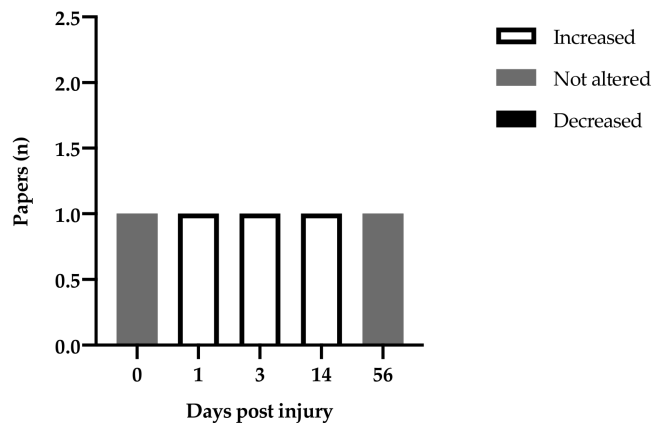

(c)

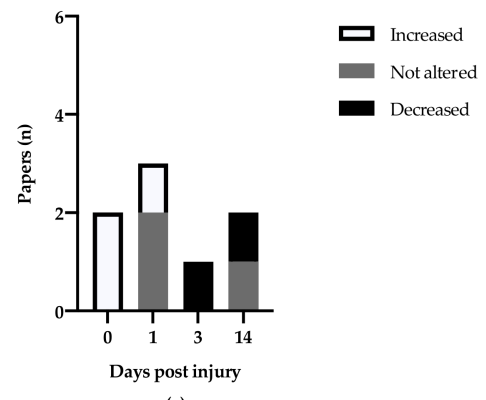

(e)

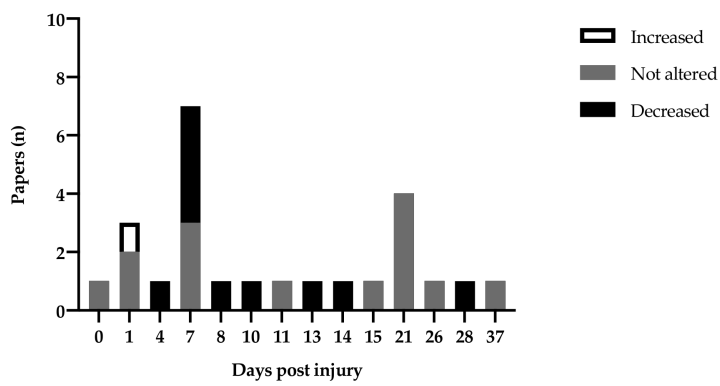

(b)

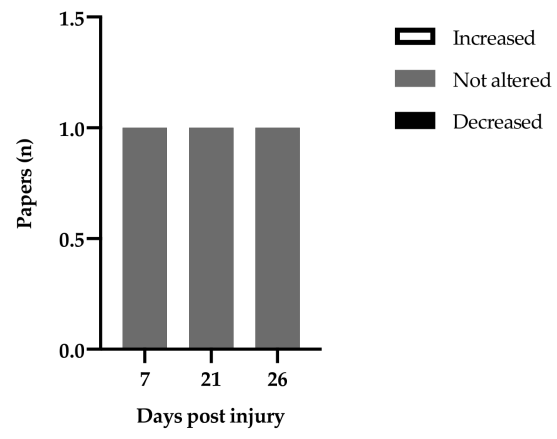

(d)

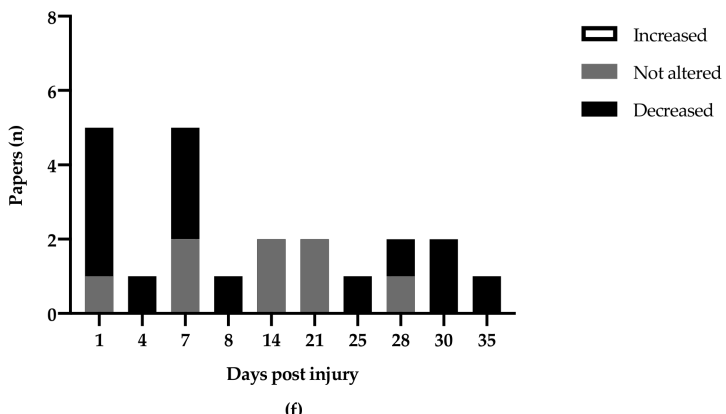

(f)

Figure 3. Overview of the number of timepoints in which brain derived neurotrophic factor (BDNF) expression was examined in the reviewed material, and whether TBI significantly increased, decreased, or was not significantly altered BDNF expression compared to sham-injured animals. (a) BDNF mRNA expression in the ipsilateral hippocampus. (b) BDNF protein expression in the ipsilateral hippocampus. (c) BDNF mRNA expression in the contralateral hippocampus. (d) BDNF protein expression in the contralateral hippocampus. (e) BDNF mRNA expression in the ipsilateral cortex (f) BDNF protein expression in the ipsilateral cortex.

Hippocampus contralateral to the injury was analyzed at six timepoints for BDNF mRNA expression and three for BDNF protein expression, ranging from $1 \mathrm{~h}$ to 56 days. Rostami et al. report that BDNF mRNA expression was increased at 1,3, and 14 days after trauma in the contralateral hippocampus, but not at the chronic phase measured at 56 days post-injury [9]. In the first day after trauma, Yang et al. reported an increased BDNF mRNA expression at 1, 3, and $5 \mathrm{~h}$ post injury. Two studies found that BDNF protein expression was non-significantly affected by trauma at timepoints 7, 21 [58], and 26 DPI [68].

\subsubsection{Cortex}

The ipsilateral cortex displays a similar pattern of expression as the ipsilateral hippocampus. During the first day post injury BDNF mRNA expression was exclusively reported as increased $[47,70]$. Kobori et al. reported an increased BDNF mRNA expression 
using rt-PCR at 2, 6, and $24 \mathrm{~h}$ after injury, but no significant change at day 3 and 14 [71]. As seen in Figure $3 e-f$, the initial increase in ipsilateral BDNF mRNA was not accompanied by a decisive increase in BDNF protein expression. Contrarily, four studies reported that BDNF protein expression was decreased in the first day, and otherwise decreased or not significantly altered by trauma at time points $4,7,8,25,28,30$, and 35 DPI $[57,69,72-87]$. The exceptions were Cekic et al. who found that CCI induced an increase in mature BDNF protein after $24 \mathrm{~h}$ and 7 days [88], as well as Nagatomo-Combs et al. who analyzed the number of BDNF-protein expressing cells in rhesus monkeys at longer time points after trauma and found an increased number of BDNF-expressing cells at 1, 6, and 12 months after injury [89].

Once again, the contralateral side is not as well examined. Corne et al. examined the cortical mRNA-expression in the contralateral parietal lobe at 21 days post-injury and reported a decrease of all BDNF exons in the TBI group compared to sham [90], while Yang et al. found no significant change in BDNF mRNA specifically in the contralateral neocortex at 1,3 , and $5 \mathrm{~h}$ after lateral cortical impact injury compared to sham-injured animals [47].

To summarize, several studies found that BDNF mRNA expression increases in the ipsilateral hippocampus and cortex in the first 1-2 days after injury and that BDNF mRNA increases in the contralateral hippocampus in days 1-14 after injury. This increase in BDNF mRNA is not accompanied by a clear increase in BDNF protein in neither cortex nor hippocampi, however the data remains insufficient to draw definitive conclusions.

\subsection{Behavioral Tests}

Several studies examining the correlation between BDNF-expression and TBI performed behavioral tests to evaluate functional outcomes, as seen in Figure 4. In the reviewed material, the most common methods of functional evaluation were Neurological Severity Score (NSS), which includes a composite of motor, sensory, reflex and balance tests, as well as Morris Water Maze (MWM), evaluating spatial memory. Novel object recognition, examining non-spatial object recognition, rotarod, evaluating balance and coordination, Open field test, assessing locomotor behavior and anxiety, Elevated Plus Maze, evaluating anxiety levels and finally, the Beam walk test, which examines balance, were used in more than 5 of the reviewed studies. The group termed "Other" includes tests that were only used in one study, such as sucrose consumption test, swing test, and tonic-clonic seizure score. A closer description regarding the behavioral tests will follow in the next section as well as in Table A1.

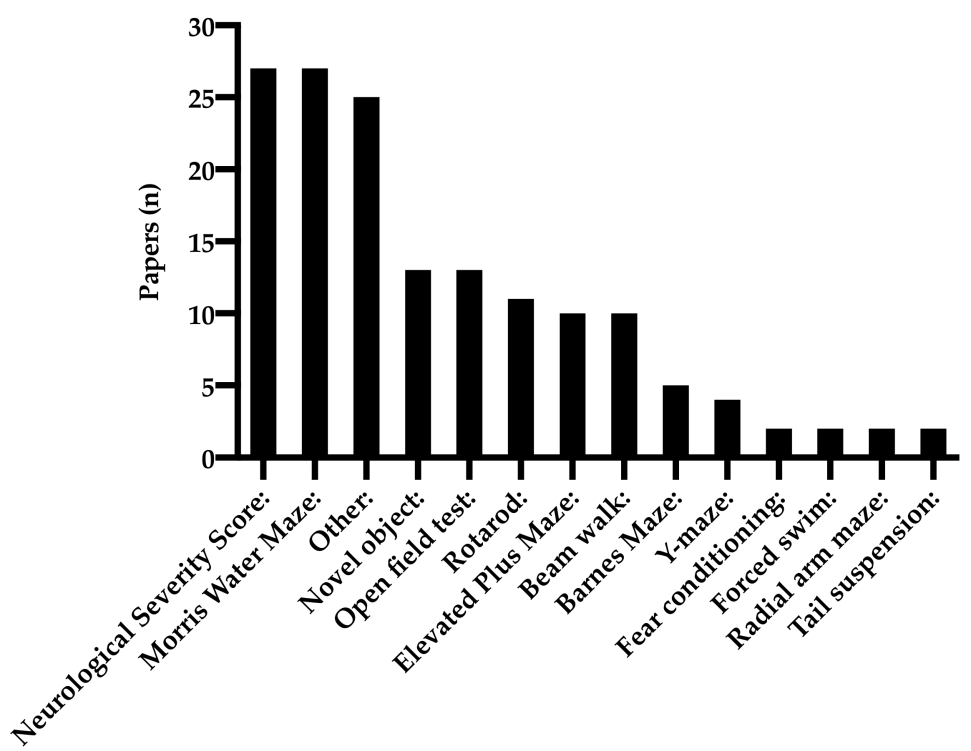

Figure 4. Behavioral tests analyzed in the reviewed material. 


\subsection{Treatment of TBI}

A total of 73 studies used various interventions to examine their effect on BDNFexpression and functional outcome following TBI, as seen in Figure 5. The most commonly investigated was the effect of exercise and diet, followed by stem cell and gonadocorticoid treatment. To review all treatments available in traumatic brain injury is beyond the scope of this review, and we have focused on reviewing exercise, diet and stem cell treatment as well as interventions affecting the intracellular pathways following BDNF-receptor activation.

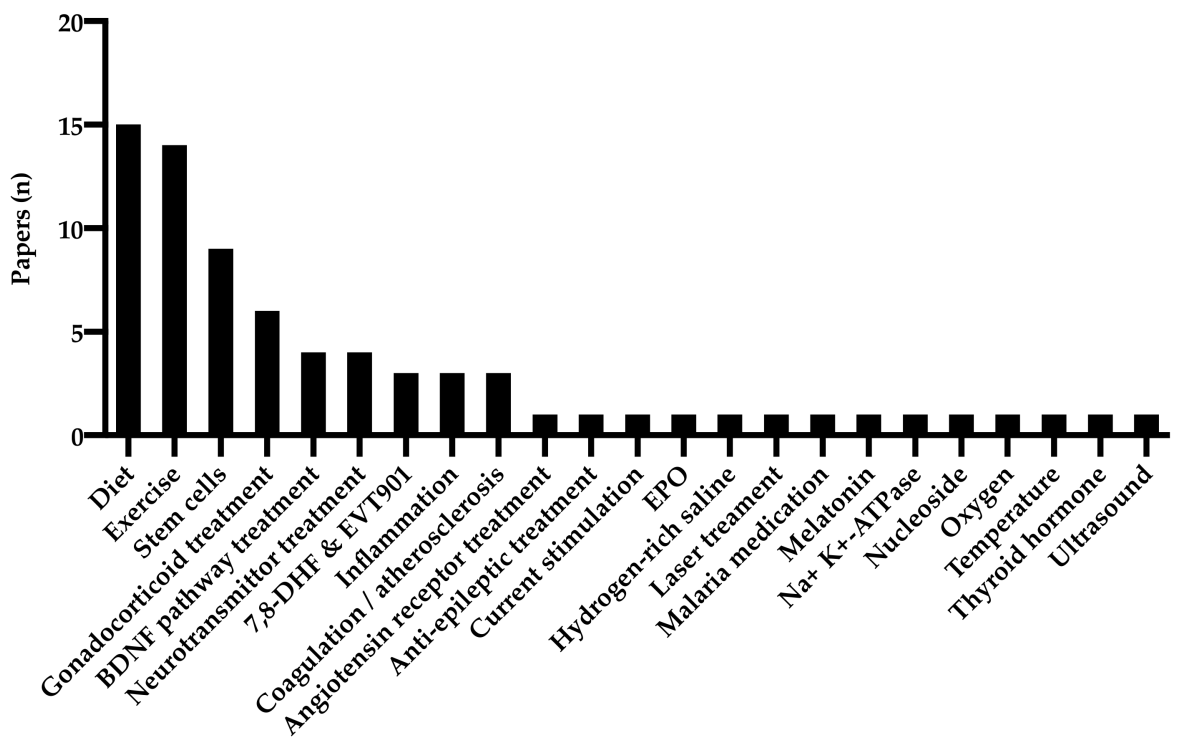

Figure 5. Treatment groups of the reviewed material.

\subsubsection{Exercise}

Exercise as a therapeutic method in traumatic brain injury was examined in 14 studies. Exactly what constituted exercise differed between the studies, but the most commonly used method was the running wheel. Some of the studies differed between voluntary and involuntary exercise, and some articles did not properly define exactly what type of exercise was performed. Out of those 14, 11 studies found that either pre- or posttraumatic exercise increased cerebral BDNF protein expression in the ipsilateral and contralateral hippocampus as well as in the ipsilateral cortex, as compared to non-exercised animals $[58,59,62-64,66-69,71,78,91-93]$. Two studies found that BDNF expression did not change significantly in rats exposed to exercise after fluid percussion injury at 7 or 11 days after injury, respectively [63,78]. Finally, Wu et al. found that exercise combined with a diet enriched with docosahexaenoic acid, a plasma membrane phospholipid, and increased BDNF protein expression compared to animals without enriched diet and inactive animals. Most of the studies found that exercise also improved functional outcome after injury. One study utilized an infrared-sensing running wheel system and trained the mice for three days before surgery and three weeks after. They found that the exercise improved short-term fear-aggravated memory and spatial memory tested by passive avoidance test and the Y-Maze test [69]. The same study also examined the HSP20 gene, a gene expressing the heat shock protein 20 which is a chaperone previously known to be expressed after tissue stress and to be protective in e.g., Alzheimer's disease. They found that silencing of the HSP20 gene canceled the exercise induced enhancement. Three studies that examined exercise found a correlation between improved BDNF protein expression (and one study found that exercise increased BDNF mRNA expression) and improved cognitive function in the Morris Water Maze test $[64,67,68,71]$. Griesbach et al. showed that exercised rats performed better in the Morris water maze test after injury compared to non-exercised rats, and that injured rats that received an inactivating TrkB-IgG antibody did not benefit from 
exercise, further suggesting that exercise exerts its ameliorating effect through the BDNF pathway [67].

Da Silva Fiorin et al. and Zhao et al. were the only ones that examined the effects of pre-traumatic exercise. da Silva Fiorin et al. found that while FPI alone had no significant effect on BDNF protein expression, previous physical exercise induced an increase in BDNF protein expression in the hippocampus at 1 and 14 DPI. Zhao et al. found that running wheel exercise for 4 weeks before trauma increased BDNF mRNA expression in the ipsilateral cortex of both sham and injured animals compared to non-exercised animals. They also found that pre-traumatic exercise improves motor function in the beam walking test and cognitive function in Morris water maze and novel object recognition tests.

Griesbach et al, utilized a voluntary wheel exercise and examined functional outcome after lateral fluid percussion and found no significant effect on gross motor impairment. Shen et al. examined different intensity training models and examined functional outcome after severe controlled cortical impact and found that while there was no significant difference between trauma groups in the Neurologic Deficit Scores, low intensity exercised animals performed better in the MWM compared to control and high intensity exercised animals. Griesbach et al. utilized a lateral fluid percussion injury model with voluntary wheel exercise and found no significant effect of exercise on BDNF expression nor the result of beam walk test $[59,68,78]$. Hicks et al. found that fluid percussion injury significantly decreased function in NSS and MWM, and that post-traumatic exercise increased BDNF protein expression but had no significant effect on NSS or the MWM [92].

\subsubsection{Diet}

A total of 15 studies examined different dietary treatment effects on traumatic brain injury in animal models. This included treatment with Astaxanthin (a sea-food derivated hermal remedy with antioxidant effects) [77], blueberry [51], caloric restriction [94], celery oil extract [82], curcumin [53,61], ethanol [95], Immunocal (a cysteine rich protein supplement) [96], procyanide [65], resolvin [97], trelahose [98], Vitamin E [60] and n-3 fatty acid treatment $[55,99]$, or $\mathrm{n}-3$ fatty acid deficiency [54].

Chandrasekar et al. examined the effect of acute ethanol intoxication in conjunction with trauma and found that trauma increased BDNF mRNA in the hippocampi bilaterally at 1 and $3 \mathrm{~h}$ after trauma compared to sham, and that the TBI-induced upregulation of BDNF was markedly decreased by ethanol pretreatment [95].

Ren et al. examined Resolvin, a docosahexaenoic (DHA) essential n-3 fatty acid derivate. The study examined BDNF protein expression in the hippocampus at 7 DPI and also found that TBI induced BDNF protein expression, and that Resolvin D1 further increased BDNF expression and ameliorated the cognitive effects of TBI in fear conditioning and beam walking tests [97].

Agrawal et al. found that FPI reduced the BDNF protein expression in the frontal cortex at 7 DPI specifically in animals exposed to $n-3$ fatty acid deficiency, but that $\mathrm{n}-3$ fatty acid pretreatment prevented this. They also showed that n-3 fatty acid treated groups spent more time in the open arms of the elevated plus maze, indicated decreased anxiety [99]. Ji et al. showed that treatment with Astaxanthin improved BDNF protein expression at 7 DPI in the ipsilateral cortex, as well as faster NSS recovery and improved performance in the rotarod test [77]. Krishna et al. found that blueberry supplementation increased BDNF protein expression in the ipsilateral hippocampus at 14 DPI, as well as improved performance in the Barnes maze, however in the elevated plus maze no significant change was seen in either trauma or treatment groups [51]. Wu et al. examined the ipsilateral hippocampus at 4 DPI and found that dietary curcumin improved BDNF protein expression after trauma as well as performance in the MWM [53]. Additionally, they later showed that dietary curcumin also improved BDNF protein expression at 8 DPI and improved outcome in the beam walk [61]. Ignowski et al. found that treatment with Immunocal increased BDNF protein expression in whole brain lysate at 3 DPI, and also improved outcomes in beam walk, rotarod, and barnes maze tests [96]. Procyanides were 
examined by Mao et al. who found that treatment increased BDNF protein expression at 14 DPI in the ipsilateral hippocampus and improved MWM performance [65]. Finally, Aiguo et al. found that Vitamin E treatment increased BDNF protein expression 1 week after trauma in the ipsilateral hippocampus and improved outcome as tested by the MWM [60]. In summary, several dietary treatments seem to impact BDNF expression and there is a correlation between increased BDNF expression and improved outcome.

\subsubsection{Stem Cell Treatment}

In the reviewed material, 9 studies examined stem cell treatments and the effect on BDNF expression after TBI. Mahmood et al. examined intravenous treatment with marrow stromal cells labeled with bromodeoxyuridine (BrdU). They found increased BrdU-positive cells in the perilesional regions, indicating the migration of marrow stromal cells (MSCs). Furthermore, they found that MSC treatment significantly increased BDNF at 8 DPI but not 2 or 5 DPI compared to vehicle. Finally, they found that the MSC-treated group had improved scores in mNSS and rotarod compared to control groups [100]. Mahmood et al. also examined long term recovery (90 DPI) and different doses of intravenous bone marrow stromal stem cells (BMSCs) treatment. They found that higher doses of BMSCs $\left(4 \times 10^{6}\right.$ and $\left.8 \times 10^{6}\right)$ significantly increased BDNF-protein levels compared to low dose $\left(2 \times 10^{6}\right)$ and vehicle. They also found that the high and intermediate dose $\left(4 \times 10^{6}\right.$ and $8 \times 10^{6}$ ) improved NSS compared to low and vehicle treated groups. Finally, they found a dose-dependent increase in perilesional GFAP expression [101]. Feng et al. examined intravenous administration BMSCs and found that BMSC-treated animals had significantly increased number of cells expressing sex determining region $\mathrm{Y}$ (SRY) co-labeled with either neural nuclear antigen (NeuN) or glial fibrillary acidic protein (GFAP) in the ipsilateral cortex of rats compared with vehicle-treated animals, indicating that BMSCs migrated to the injured region and differentiated to neurons and astrocytes. Furthermore, they found that TBI alone had no effect on BDNF protein expression at 14 DPI the ipsilateral cortex, but that BMSC treatment significantly increased BDNF protein expression compared to both sham and trauma groups [81]. Deng et al. examined the interaction between BMSC treatment and stromal cell-derived factor-1 (SDF-1), which is a chemokine involved in the migration and survival of stem cells. Specifically, they examined posttraumatic micro injection of BMSCs cultured in solutions with and without SDF-1. They found that the number of BDNF-positive cells increased in the BMSC-treated group and further increased in the group treated with BMSC cultured with SDF-1. Furthermore, they found that the BMSC+SDF-1 group had better outcome in NSS and MWM tests compared to both BMSC without SDF-1 and vehicle groups [102]. Kim et al. found that BDNF protein increased in the ipsilateral hemisphere at 2 DPI, but found no significant expression change at 8,15 , or 29 DPI in TBI groups compared to sham. They also found that intravenous treatment with human mesenchymal stem cells (hMSCs) further increased BDNF expression at day 2 but had no significant effect at the other dates post injury. Although hMSC migration to the injured zone was confirmed by anti-human nuclei antibody staining at 2 DPI, the increase was transient and found to be decreased at 15 DPI. Additionally, there was only a small increase in NeuN or GFAP positive cells. Finally, they found that hMSCs improved outcome in the rotarod and mNSS tests compared to the vehicle treated TBI group [103]. Qi et al. examined umbilical cord mesenchymal stem cells (UC-MSCs) transplanted into the perilesional region and found that UC-MSCs increased BDNF protein expression at 2, 3, and 4 weeks, but not at 1 week, after injury compared to vehicle treated TBI. Furthermore, they found that UC-MSC treated group had an increased number of GFAPpositive cells as well as improved scores in NSS compared to vehicle [104]. Wang et al. found that intraventricular UC-MSC transplantation significantly increased the number of BDNF-positive and GFAP-positive cells compared to the control group. Additionally, they found that the UC-MSC-treated group had lower scores in NSS compared to the control [105]. Cheng et al. examined Wharton's Jelly, which is an umbilical cord matrix including human umbilical cord-mesenchymal stem cells. They found no significant 
change in BDNF protein expression in the ipsilateral cortex at 14 DPI in sham compared to trauma groups, but that both BDNF protein and mRNA were significantly higher in the TBI group that received Wharton's Jelly transplantation into the perilesional region compared to vehicle-treated rats [72]. Xiong et al. found that trauma decreased BDNF protein expression in the ipsilateral cortex at 7 DPI. They examined neural stem cells (NSC) from neonatal hippocampi incubated for neurosphere formation, as well as neurospheres derived from BDNF knockdown mice. They found that transplantation of NSCs into the perilesional region reversed the reduction of BDNF protein levels, and that BDNF knockdown neurospheres produced less BDNF and synaptophysin. In addition to this, they found that NSC-treated mice had decreased NSS compared to mice treated with the BDNF-KD NSCs as well as the vehicle treated TBI group. The NSC-treated group also had improved performance in the rotarod test compared to the vehicle-treated TBI-group. In conclusion, they found that NSCs transplantation increased BDNF expression and improved outcome in NSS and rotarod tests through BDNF-activation [79].

In summary, all the reviewed studies examining stem cell treatment found that several types of stem cells increased BDNF expression. Five out of nine studies did not include a sham group separate from vehicle or trauma. Regarding functional outcomes, the two studies examining umbilical cord stem cell transplantation together with the study examining Wharton's Jelly transplantation found improved neurological severity scores in treatment groups compared to vehicle $[72,104,105]$. The study examining Wharton's Jelly also found that treated rats spent more time in the correct quadrant and had shorter latency to find the platform in the MWM, as well as spent significantly more time exploring the novel object in the novel object recognition test. This indicates that Wharton's Jelly transplantation improves spatial and object recognition memory after TBI in rats. The three studies examining marrow stromal treatment found improved NSS in treatment groups compared to vehicle groups, and two of them also found improved motor deficits in the rotarod test in marrow derived stem cell treated groups compared to control $[81,100,101]$. Marrow stem cells also improved outcome in both shorter escape latency times and number of platform crossings compared to control in the MWM, indicating improved spatial memory [102]. In the study examining human mesenchymal stem cell transplantation, they found improved outcome in NSS and rotarod tests in treated groups compared to control [103]. Finally, the study examining neural stem cells found that treated groups had improved NSS outcome as well as motor function in the rotarod test after trauma [79].

\subsubsection{BDNF Pathway Treatment}

The number of studies examining direct intervention of the BDNF pathway in TBI are few, and this review included four studies. Sen et al. found that TBI decreased BDNF protein expression in the ipsilateral cortex 21 days following injury. Furthermore, they examined the Protein kinase-like endoplasmic reticulum kinase (PERK), a kinase in the endoplasmic reticulum activated by stress such as TBI, which mediates the downstream inhibition of translation. Previous studies have found that phosphorylation of PERK leads to an increased activation of CREB and thus the downregulation of BDNF. They found that a PERK antagonist GSK2656157 increased BDNF expression and improved cognitive performance in the Morris Water Maze test. This indicates that the inhibition of this pathway increased BDNF protein expression which could contribute to the improved performance in the MWM [83]. Alders et al. and Yin et al. examined BDNF fused with a collagen-binding domain, and BDNF expression in the ipsilateral cortex at 28 days after injury and found that BDNF was most increased in the mice treated with BDNF fused with the collagen-binding domain, followed by animals treated with only BDNF followed by TBI. They found no significant difference in BDNF expression between sham animals and injured mice $[57,86]$.

BDNF have a short half-life and low blood brain barrier permeability, and one group used nanoparticles coated by surfactant, poloxamer 188 (PX), to increase BDNF concentration in target areas. They found that TBI increased BDNF protein expression in ipsilateral 
and contralateral hemispheres $4 \mathrm{~h}$ after injury. Furthermore, BDNF expression was increased ipsilaterally in animals treated with BDNF together with nanoparticles with and without PX compared to vehicle and BDNF without nanoparticle treatment groups. Contralaterally BDNF expression was only increased in the group treated with BDNF together with the combination of nanoparticles and PX. In the functional evaluations, they found a spontaneous improvement of NSS in day 1 to 6 , with no difference between groups. However, at day 7 there was a significant improvement of NSS in the group treated with BDNF together with both nanoparticles and PX group compared to the other treatment groups. In the Passive avoidance test, the sham group and group treated with BDNF together with both nanoparticle and PX outperformed the other groups which performed no better than the non-treated animals [106].

\subsubsection{7,8-DHF \& EVT901}

Recently, the synthetic flavonoid 7,8-dihydroxyflavone (7,8-DHF) was discovered following a screening for small molecules that could selectively activate BDNF receptor TrkB. This means that 7,8-DHF may cause similar effects, as BDNF in the brain, and be more therapeutically useful due to its better absorption and ability to cross the blood-brain barrier. The 7,8-DHF has shown an ability to promote the growth of these dendrites into synapses to help restore communication between neurons in animal models of cognitive decline.

In an experimental TBI model administration of $7,8-\mathrm{DHF}$ prior to injury reduced cell death of neurons in the hippocampus. Reduced cell necrosis and apoptosis could also be seen upon administration of (7,8-DHF) after simulated TBI in adult mice [107]. Recently 7,8-DHF treatment was combined with exercise post-injury in rats and showed to promotes enhanced levels of cell metabolism, synaptic plasticity and increased brain circuit function [108].

Additionally, a selective antagonist of p75NTR, EVT901, was recently identified [109]. EVT901 inhibits p75NTR in vitro while increasing TrkA phosphorylation, blocks apoptosis and increases neurite outgrowth in neuroblastoma cells. Furthermore, treatment with EVT901 in TBI exposed rats reduced neuronal death in the hippocampus and thalamus, reduced long-term cognitive deficits, and reduced the occurrence of post-traumatic seizure activity.

These two newly discovered drugs showed no harmful effect in animal models and, offer a promising opportunity for complementary pharmacological treatment of TBI.

\subsection{BDNF in Transgenic Animals}

BDNF expression in transgenic animals after TBI is a novel field, and we have included a total of three studies. The results of these studies naturally vary from non-transgenic animals and because of this the results and methods of these studies have not been included in the previous graphs.

Giarratana et al. examined Val66Met-transgenic mice (Met+) and utilized a repeated mild TBI model using a lateral fluid percussion injury model. Giarratana et al. found that the total BDNF protein was decreased in Met+ injured animals in the ipsilateral cortex at $21 \mathrm{DPI}$, but that pro/mature-BDNF protein was increased in the ipsilateral hippocampus at 1 DPI compared to Met-. Furthermore, they found that Met+-animals had larger volume of inflammation compared to Val66Val at 21 DPI and that Met+animals had an increased activation of microglia in both hippocampal and cortical tissues at both 1 and 21 DPI. Met+ also have increased activation of Caspase-3+ cells (a marker for apoptosis) compared to Metat 1 DPI, and have increased levels of FluorojadeC + cells (a marker for neurodegeneration) compared to Met- at 1 and 21 DPI. Finally, they also found that Val66Met-injured animals had an increased number of phosphorylated tau+ cells (a marker for neurodegenerative pathology) compared to Met- at 1 and 21 DPI, and an increased number of GFAP+ cells in the ipsilateral cortex in Met+ compared to Met- at 21 DPI, but not 1 DPI, indicating increased astrocyte activation and risk of glial scarring [110]. 
Gao et al. utilized a cre/flox conditional knockout (KO) of BDNF which enables a sitespecific knockout of BDNF in the granular neurons of the dentate gyrus of the hippocampus. In the flox/flox control animals, they found that TBI increased BDNF protein expression in the hippocampus. In the conditional $\mathrm{KO}$ animals, they found significantly decreased BDNF levels in the dentate gyrus in sham treated animals, and that TBI increased the levels of BDNF protein in the dentate gyrus of $\mathrm{KO}$ mice to a lesser extent that the increase of flox/flox control animals. Furthermore, they found significantly increased number of FJB+-cells in $\mathrm{KO}$ animals compared to injured flox/flox control animals, which indicates that the conditional knockout of BDNF leads to increased cell death in the dentate gyrus after trauma. Moreover, they showed that TBI injury significantly induces newborn neuron death $24 \mathrm{~h}$ following moderate TBI injury, and that the BDNF conditional KO further increases newborn neuron death in the dentate gyrus [111].

Cheng et al. studied thrombospondin-1 (TSP-1) KO animals after controlled cortical injury. TSP-1 is an extracellular matrix protein secreted by astrocytes in the brain and has been linked to several cerebral pathologies. Chang et al. found that in wild type (WT) animals, TSP- 1 increased in the ipsilateral cortex at $6 \mathrm{~h}$ to 3 days, then returned to normal levels. Examining the relationship with BDNF expression, they found that TBI increased BDNF protein expression in both the contra- and ipsilateral cortex in WT at 21 days after trauma. However, in TSP-1 KO BDNF increased only in the ipsilateral cortex and not in the contralateral cortex. This might hint at a TSP-1 gene depletion-associated resistance of BDNF. Moreover, they found that measurement of synaptophysin (a marker for synapse quantification) showed no difference between $\mathrm{KO}$ and WT groups before TBI, but that TBI similarly significantly decreased synaptophysin in the contralateral cortex compared to sham and WT. There was no significant difference in synaptophysin expression in the ipsilateral cortex between groups. Furthermore, TBI increased extravasation in the ipsilateral hemisphere, which was significantly exasperated in TSP-1 KO mice compared to WT. In the functional tests, TSP-1 KO significantly worsened performance in NSS compared to WT post-TBI, indicating worse motor-sensor response. Wire grip and corner test was not significantly different in $\mathrm{KO}$ and WT groups and returned to normal at $10 \mathrm{DPI}$. In the MWM, TSP-1 KO mice had increased latency to find the platform compared to WT, but no significant difference in entry times or target quadrant. TSP-1 KO might worsen spatial memory recovery after TBI [112].

\section{Discussion}

The reviewed material is very heterogenous regarding the examined brain regions, temporal analysis of BDNF-expression after injury, type of trauma model, and functional tests, as well as whether a sham group was presented or reported. There is an urgent need for the standardization of experimental design in order to provide more reproducible results and solid conclusions. Nevertheless, there is an overall pattern of transiently increased BDNF-mRNA expression in the first day after trauma in the ipsilateral hippocampus followed by an ipsilateral decrease and a contralateral increase. Similarly, in the ipsilateral cortex, BDNF-mRNA increased in the first day after trauma, followed by a tendency of decreased expression.

Regarding the human studies, there is a similar need for standardization and larger cohorts. Generally, the studies are small, most have a study population $<200$ individuals and a control group has not always been used. Outcome measures differ among the studies, especially when evaluating cognitive function. Additionally, the time point for follow up varies between the studies and the access of prospective studies are scarce. The met/met prevalence in Caucasian population is low and therefore most studies group met-heterozygote and homozygote together for analysis which begs the question if the functional effect is the same and whether the met+ result in a lower baseline of cognitive function but offer a protective quality of cognition post TBI. 


\subsection{Human Induced Pluripotent Stem Cell-Models in TBI Research}

As previously described, TBI is a heterogenous and complex condition involving multiple CNS cell types. Cellular interactions and subcellular processes follow temporal and spatial patterns that vary between affected individuals, and between different injuries. Accordingly, experimental TBI is usually studied using in vivo models, typically rodents, recapitulating many of the aforementioned features. However, certain aspects of TBI, such as the contribution of cell autonomous versus non-cell autonomous factors may also be studied in vitro, allowing for more mechanistic studies of isolated processes. In addition, a disadvantage with the current in vivo models is possible differences between human and animal cells regarding gene and protein expression or response to pharmacological interventions. These differences may underly some of the difficulties in translating results from basic research to clinical applications.

\subsection{Potential Advantages with iPSC-Models}

In line with the literature, we propose that in vitro models using neuronal cell types differentiated from induced pluripotent stem cells (iPSCs) from human subjects could be used as a complementary model, e.g., for studying cell to cell interactions, diffuse axonal injury (DAI), neuroinflammation, and the screening of neuroprotective drugs [113-115]. Advantages using iPSC-based models include that no experimental animals are required; the impact of genetic variations can be studied at the cellular level; ability to study human neurons, which are not accessible in live patients; and that pharmacodynamic and pharmacokinetic properties of potential drugs can be determined in the target human cell types. Moreover, subpopulations of neurons and glial cells of interest can be studied individually or in co-cultures.

More advanced models include the use of brain organoids derived from iPSCs, which better resemble the three-dimensional environment in the brain and allow for more complex analyses [116,117], but entails challenges regarding data acquisition and analysis. Notably, these models may also recapitulate non-acute aspects of TBI, including aggregation of hyperphosphorylated tau and tar DNA-binding protein 43 (TDP43) [117], which has been linked to neurodegenerative processes such as chronic traumatic encephalopathy (CTE).

\subsection{Studying the Impact of BDNF Val66met Polymorphism}

We propose that studies of iPSC-derived neurons and glia from TBI patients with $B D N F$ val66met polymorphisms could give clues about how this genetic variation influences, e.g., secretion and signaling of BDNF, synaptic plasticity and neuronal and glial response to injury. Moreover, such a model would be well-suited for pharmacodynamic and pharmacokinetic studies of the effects of the two potential neuroprotective compounds 7,8-DHF and EVT901.

However, since the val66met polymorphism has been linked to various neurodevelopmental and neurodegenerative disorders [118,119], we therefore propose that detection of TBI-associated phenotypes primarily requires the combination with an established in vitro model for TBI, such as scratch, blast, high intensity focused ultrasound, hypoxia or stretch injuries $[113,117]$.

\subsection{Considerations Regarding Translation to Humans}

It should be considered that the monumental leap from patient to cells in a dish may result in subtle, artefactual or clinically irrelevant phenotypes [113]. Therefore, when designing such study, the hypothesis must be clearly defined and based on existing knowledge, rather than being a screening method for cellular phenotypes.

Moreover, it should be considered that single nucleotide polymorphisms (SNP) often result in subtle and multifactorial phenotypes, which may involve "multiple hits" in patients. Certain phenotypes associated with SNPs may therefore not manifest in vitro.

Since iPS cells derived from humans are genetically heterogenous, phenotypic differences between a patient line and a control line may be due to other factors than the ones 
intended to study. One approach to overcome this problem could be to use multiple control lines, but as proof-of-concept, one would modify the genetic variation in the patient line of interest using targeted gene correction in order to create an isogenic control line.

In summary, iPSC based TBI models could be useful in the studies of how genetic variations in the $B D N F$ gene affects neuronal and glial function, and to evaluate new drug candidates, but should be used wisely in order to generate clinically relevant result.

\subsection{Treatment of TBI and Future Research}

Regarding the treatment of traumatic brain injury, several of the studies showed promising results and there is evidence of a positive correlation between increased BDNF expression and improved functional outcome, at least in animal studies. This is made especially clear in the cases where the positive effects of the treatment were cancelled by a BDNF antagonist, but unfortunately this was not often utilized in the reviewed material.

Traumatic brain injury is a global health issue with potentially devastating life-long consequences for the individual patient. Both injury and rehabilitation are very complex, and more research is necessary in order to understand the pathological mechanisms, and to provide novel treatment options of the primary injury. The treatment of the BDNF pathway could provide a novel treatment option in improving functional outcomes. Although treatment potential with the BDNF-molecule itself is limited because of low permeability of the blood brain barrier and a short half-life, an option could be TrkB-agonist treatment, such as 7, 8-dihydroxyflavone.

Author Contributions: D.G., A.K., S.T. and E.R., wrote the manuscript. D.G. created the figures. E.R. provided conceptualization, supervision and revision. All authors have read and agreed to the published version of the manuscript.

Funding: Elham Rostami is a Wallenberg Clinical Fellow supported by SciLife, the Swedish Society for Medical Research.

Institutional Review Board Statement: Not applicable.

Informed Consent Statement: Not applicable.

Data Availability Statement: Not applicable.

Conflicts of Interest: The authors declare no conflict of interest.

\section{Appendix A}

Table A1. Overview of the reviewed studies examining humans and a short summary of their reported results.

\begin{tabular}{|c|c|c|c|c|c|c|c|}
\hline & Total N & TBI & Age & Timing & BDNF SNP & $\begin{array}{l}\text { Outcome } \\
\text { Assessed }\end{array}$ & Findings \\
\hline \multicolumn{8}{|l|}{$\begin{array}{l}\text { BDNF Global } \\
\text { Outcome }\end{array}$} \\
\hline $\begin{array}{c}\text { (Failla et al. 2016) } \\
\text { [33] }\end{array}$ & $\begin{array}{l}203 \text { and } \\
10 \text { controls }\end{array}$ & Severe TBI & $16-74 y$ & $0-7 d+8-365 d$ & $\begin{array}{l}\text { Rs6265 and } \\
\text { rs7124442 } \\
\text { (c-carrier) }\end{array}$ & $\begin{array}{l}\text { CSF and serum } \\
\text { BDNF levels. } \\
\text { Mortaility } \\
\text { GOS-scores }\end{array}$ & $\begin{array}{l}\text { BDNF-GRS + serum } \\
\text { BDNF predictive } \\
\text { of mortality }\end{array}$ \\
\hline $\begin{array}{c}\text { (Failla et al. 2015) } \\
\text { [18] }\end{array}$ & 315 & Severe TBI & $16-75 y$ & $0-7 d+8-365 d$ & $\begin{array}{l}\text { Rs6265 and } \\
\text { rs7124442 } \\
\text { (c-carrier) }\end{array}$ & $\begin{array}{c}\text { Mortality GOS } \\
\text { BDNF-GRS }\end{array}$ & $\begin{array}{l}\text { BDNF met-carrier higher } \\
\text { mortality first year and } \\
\text { long term in younger } \\
\text { individuals }(<45 \mathrm{y}) \text {, lower } \\
\text { mortality }>45 \mathrm{y} \text {. }\end{array}$ \\
\hline $\begin{array}{l}\text { (Munoz et al. } \\
\text { 2017) [19] }\end{array}$ & 117 & Severe TBI & $16-73$ y & 6 months & $\begin{array}{l}\text { Rs6265 and } \\
\text { rs7124442 } \\
\text { (c-carrier) }\end{array}$ & $\begin{array}{l}\text { Mortality GOS } \\
\text { CSF cortisol } \\
\text { CSF/serum BDNF } \\
\text { BDNF-GRS }\end{array}$ & $\begin{array}{l}\text { BDNF-GRS predict } \\
\text { mortality } \\
\text { CSF levels of BDNF in } \\
\text { association with CSF } \\
\text { cortisol correlate } \\
\text { to mortality }\end{array}$ \\
\hline \multicolumn{8}{|l|}{ BDNF cognition } \\
\hline $\begin{array}{l}\text { (Bagnato et al. } \\
\text { 2012) [39] }\end{array}$ & 53 & Vegetative & $15-55 y$ & $1-12 \mathrm{~m}$ & $\begin{array}{c}\text { Rs6265 } \\
2 \text { groups val/val + } \\
\text { ohters }\end{array}$ & $\begin{array}{c}\text { Levels of } \\
\text { cognitive function } \\
1-8\end{array}$ & $\begin{array}{l}\text { No difference in LCF } \\
\qquad(1-8)\end{array}$ \\
\hline $\begin{array}{l}\text { (Barbey et al. } \\
\text { 2014) [40] }\end{array}$ & 156 & $\begin{array}{l}\text { Penetrating, } \\
\text { frontal lobe } \\
\text { lesion }\end{array}$ & & $30-40 y$ & $\begin{array}{c}\text { Rs } 6265 \\
2 \text { groups val/val + } \\
\text { ohters }\end{array}$ & WAIS & $\begin{array}{l}\text { val/val 6-8 lower } \\
\text { IQ score }\end{array}$ \\
\hline
\end{tabular}


Table A1. Cont.

\begin{tabular}{|c|c|c|c|c|c|c|c|}
\hline & Total N & TBI & Age & Timing & BDNF SNP & $\begin{array}{l}\text { Outcome } \\
\text { Assessed }\end{array}$ & Findings \\
\hline $\begin{array}{l}\text { (Krueger et al. } \\
\text { 2011) [16] }\end{array}$ & $\begin{array}{l}168 \text { and } \\
47 \text { controls }\end{array}$ & $\begin{array}{l}\text { Penetrating, } \\
\text { frontal lobe } \\
\text { lesion }\end{array}$ & $52-70 \mathrm{y}$ & $\mathrm{Ca} 40 \mathrm{y}$ & $\begin{array}{c}\text { Rs } 6265 \\
2 \text { groups val/val }+ \\
\text { others }\end{array}$ & $\begin{array}{l}\text { D-KEFS cognitive } \\
\text { and executive } \\
\text { function }\end{array}$ & $\begin{array}{l}\text { Val/val post TBI } \\
\text { lower score }\end{array}$ \\
\hline $\begin{array}{l}\text { (McAllister et al. } \\
\text { 2012) [17] }\end{array}$ & $\begin{array}{l}75 \text { and } 38 \\
\text { controls }\end{array}$ & $\begin{array}{l}\text { Mild/moderate } \\
\text { TBI }\end{array}$ & 33.1 y mean & 1 month & $\begin{array}{l}\text { Rs6265 (3 groups) } \\
\text { Rs11030102 } \\
\text { Rs11030107 } \\
\text { Rs12273363 }\end{array}$ & $\begin{array}{c}\text { CVLT } \\
\text { CPT Gordon } \\
\text { WAIS + WRAT for } \\
\text { baseline. }\end{array}$ & $\begin{array}{l}\text { Met/met slower RT, no } \\
\text { difference between TBI } \\
\text { and controls }\end{array}$ \\
\hline $\begin{array}{l}\text { (Merritt et al. } \\
\text { 2020) [28] }\end{array}$ & $\begin{array}{l}75 \text { and } \\
63 \text { military } \\
\text { controls }\end{array}$ & Mild TBI & $22-53 \mathrm{y}$ & Mean 66.7 months & Rs6265 (2 groups) & $\begin{array}{l}\text { WRAT } \\
\text { D-KEFS } \\
\text { CVLT-II } \\
\text { RCFT } \\
\text { WAIS }\end{array}$ & $\begin{array}{l}\text { Met-carriers better } \\
\text { memory and executive } \\
\text { function post TBI. } \\
\text { Reverse for controls. }\end{array}$ \\
\hline $\begin{array}{l}\text { (Narayanan et al. } \\
\text { 2016) [27] }\end{array}$ & 48 & Mild TBI & $18-53 \mathrm{y}$ & $\begin{array}{l}10 \mathrm{~h} \text { post GCS } 15 \\
\text { and } 6 \text { months }\end{array}$ & $\begin{array}{c}\text { Rs6265 (2 groups) } \\
\text { Rs1048218 } \\
\text { Rs1048220 } \\
\text { Rs1048221 } \\
\text { Rs8192466 } \\
\text { Rs139352447 }\end{array}$ & S-NAB & $\begin{array}{l}\text { Met-carriers worse } \\
\text { memory at } 6 \text { months }\end{array}$ \\
\hline $\begin{array}{l}\text { (Rostami et al. } \\
\text { 2011) [20] }\end{array}$ & $\begin{array}{l}109 \text { and } \\
38 \text { controls }\end{array}$ & $\begin{array}{c}\text { Focal, } \\
\text { penetrating TBI }\end{array}$ & & $\begin{aligned} \text { Phase II } & =10-15 \mathrm{y} \\
\text { Phase III } & =30-35 \mathrm{y}\end{aligned}$ & $\begin{array}{c}\text { Rs1519480 } \\
\text { Rs7124442 } \\
\text { rs6265 } \\
\text { rs7934165 } \\
\text { Rs11030121 } \\
\text { Rs12273363 } \\
\text { Rs908867 }\end{array}$ & $\begin{array}{c}\text { Army Force } \\
\text { Qualification Test } \\
\text { WAIS }\end{array}$ & $\begin{array}{l}\text { C/C of Rs1519480 (and } \\
\text { Rs7124442 = worse } \\
\text { performance phase II, } \\
\text { unchanged phase III }\end{array}$ \\
\hline \multicolumn{8}{|l|}{$\begin{array}{c}\text { BDNF } \\
\text { psychological } \\
\text { factors }\end{array}$} \\
\hline $\begin{array}{l}\text { (Dretsch et al. } \\
\text { 2016) [24] }\end{array}$ & $\begin{array}{c}231 \text { of } \\
458 \text { soldiers }\end{array}$ & Mild TBI & & $\begin{array}{l}\text { Within } 30 \text { days of } \\
\text { return }\end{array}$ & $\begin{array}{l}\text { Rs6265 (3 groups) } \\
\text { (APOE, DRD2) }\end{array}$ & $\begin{array}{l}\text { Pre- and post } \\
\text { deployment: } \\
\text { CNS-VS } \\
\text { Neurobehavioral } \\
\text { Symptom } \\
\text { Inventory }\end{array}$ & $\begin{array}{l}\text { Met-homozygote higher } \\
\text { incidence of mTBI } \\
\text { Met-homozygote higher } \\
\text { incidence of PTSD }\end{array}$ \\
\hline $\begin{array}{l}\text { (Gabrys et al. } \\
\text { 2019) [120] }\end{array}$ & 219 & Mild TBI & & Life time & Rs6265 (2 groups) & $\begin{array}{c}\text { WCST } \\
\text { Subtypes of } \\
\text { rumination BDI } \\
\text { (Beck Depression } \\
\text { Inventory) }\end{array}$ & $\begin{array}{l}\text { Met-carriers with history } \\
\text { of mTBI had a higher } \\
\text { frequency of brooding, } \\
\text { depressive symtoms and } \\
\text { less cognitive flexibility. } \\
\text { More pronounced } \\
\text { difference among } \\
\text { female participants. }\end{array}$ \\
\hline $\begin{array}{l}\text { (Lanctt et al. } \\
\text { 2010) [38] }\end{array}$ & 90 & $\begin{array}{l}\text { Mild/moderate } \\
\text { TBI }\end{array}$ & Mean $39.9 \mathrm{y}$ & Unknown & $\begin{array}{c}\text { Rs6265 } \\
\text { 5HT1A/2A TPH2 } \\
\text { MTHFR } \\
\end{array}$ & HAMD & $\begin{array}{l}\text { Val-homozygote better } \\
\text { responders to Citalopram }\end{array}$ \\
\hline $\begin{array}{l}\text { (Wang et al. } \\
\text { 2018) [36] }\end{array}$ & $\begin{array}{l}192 \text { (103 in the } \\
\text { follow up) }\end{array}$ & Mild TBI & $20-83$ y & $\begin{array}{c}1 \text { week and } 6 \\
\text { weeks }\end{array}$ & $\operatorname{Rs6265}(\mathrm{C} / \mathrm{T})$ & $\begin{array}{l}\mathrm{BAI} \\
\mathrm{BDI}\end{array}$ & $\begin{array}{l}\text { Male, T-carriers had more } \\
\text { anxiety and depression }\end{array}$ \\
\hline BDNF other & & & & & & & \\
\hline $\begin{array}{l}\text { (Hunter et al. } \\
\text { 2019) [32] }\end{array}$ & $\begin{array}{l}312+110 \\
\text { controls }\end{array}$ & $\begin{array}{c}\text { Heading } \\
\text { (subconcussive } \\
\text { brain injury) }\end{array}$ & $18-55 y$ & $\begin{array}{l}\text { Baseline and } 24 \\
\text { months follow up }\end{array}$ & Rs6265 (2 groups) & $\begin{array}{l}\text { Heading self } \\
\text { report } \\
\text { MR DTI }\end{array}$ & $\begin{array}{l}\text { Met-carriers had less } \\
\text { remyeliniation if } q 4 \\
(>1460 \text { headings) }\end{array}$ \\
\hline $\begin{array}{l}\text { (Larson-Dupuis } \\
\text { et al. 2015) [25] }\end{array}$ & $\begin{array}{l}54 \text { and } \\
51 \text { controls }\end{array}$ & Concussion & $\begin{array}{l}\text { Mean } 20.8 \mathrm{y} \\
(3-85 \mathrm{y})\end{array}$ & Mean 27 months & Rs6265 (3 groups) & $\begin{array}{c}\text { Sniffin' Sticks } \\
\text { Inventory Test } \\
\text { PCS-scale }\end{array}$ & $\begin{array}{l}\text { Val-homozygote with } \\
\text { history of mTBI had } \\
\text { worse olfactory function }\end{array}$ \\
\hline $\begin{array}{l}\text { (Hayes et al. } \\
\text { 2018) [21] }\end{array}$ & $\begin{array}{l}110 \text { and } 55 \\
\text { controls }\end{array}$ & Mild TBI & $19-58$ y & $\mathrm{N} / \mathrm{A}$ & $\begin{array}{l}\text { BDNF Rs1157659 } \\
\text { Rs 6265) }\end{array}$ & $\begin{array}{l}\text { Hippocampal } \\
\text { volume on MRI } \\
\text { fMRI-functional } \\
\text { connecticity }\end{array}$ & $\begin{array}{l}\text { Rs1157659 minor allele } \\
\text { homozygote had reduced } \\
\text { functional connectivity in } \\
\text { defualt mode network } \\
\text { and smaller } \\
\text { hippocampal volume }\end{array}$ \\
\hline
\end{tabular}

BDNF GRS = genetic risk score based on genetic profile and age.

Table A2. Overview of the reviewed studies examining animals and a short summary of their reported results.

\begin{tabular}{|c|c|c|c|c|c|c|c|c|}
\hline $\begin{array}{l}\text { BDNF Animal } \\
\text { Studies }\end{array}$ & $\mathbf{N}=$ & Animal & $\begin{array}{l}\text { Trauma } \\
\text { Model }\end{array}$ & $\begin{array}{c}\text { BDNF } \\
\text { Analysis }\end{array}$ & $\begin{array}{c}\text { Site of } \\
\text { Analysis }\end{array}$ & $\begin{array}{c}\text { Date of } \\
\text { Analysis }\end{array}$ & BDNF Expression & Functional Tests \\
\hline $\begin{array}{l}\text { (Edut et al. } \\
\text { 2014) [121] }\end{array}$ & 9-13/group & Mouse & Weight drop & Western blot & $\begin{array}{l}\text { Cortex, } \\
\text { striatum }\end{array}$ & $\begin{array}{c}1 \mathrm{~h}, 24 \mathrm{~h}, 72 \mathrm{~h}, \\
7 \text { days and } 30 \\
\text { days }\end{array}$ & $\begin{array}{l}\text { Not altered by trauma, } \\
\text { not altered by treatment } \\
\text { at any timepoints }\end{array}$ & $\begin{array}{l}\text { Novel object } \\
\text { recognition, } \\
\text { Y-maze }\end{array}$ \\
\hline $\begin{array}{c}\text { (Sen et al. 2017) } \\
\text { [83] }\end{array}$ & 8-10/group & Mouse & $\mathrm{CCI}$ & Western blot & Site of impact & 25 days & $\begin{array}{l}\text { Decreased by trauma, } \\
\text { increased by treatment at } \\
\text { all timepoints }\end{array}$ & $\begin{array}{l}\text { Morris Water } \\
\text { Maze }\end{array}$ \\
\hline $\begin{array}{c}\text { (Li et al. 2017) } \\
\text { [122] }\end{array}$ & $20 /$ group & Rat & FPI & $\begin{array}{l}\text { Western blot and } \\
\text { ELISA }\end{array}$ & $\begin{array}{c}\text { "tissue } \\
\text { homogenates" }\end{array}$ & $\begin{array}{l}6 \mathrm{~h}, 12 \mathrm{~h}, 48 \mathrm{~h}, \\
96 \mathrm{~h} \text { and } 168 \mathrm{~h}\end{array}$ & $\begin{array}{c}\text { No sham. Increased by } \\
\text { treatment at all } \\
\text { timepoints }\end{array}$ & $\begin{array}{c}\text { Beam walking } \\
\text { test, Morris } \\
\text { Water Maze, and } \\
\text { modified } \\
\text { Neurological } \\
\text { Severity Score }\end{array}$ \\
\hline $\begin{array}{l}\text { (Rostami et al. } \\
\text { 2014) [9] }\end{array}$ & 3-4/group & Rat & $\begin{array}{l}\text { Penetrating } \\
\text { injury }\end{array}$ & $\begin{array}{l}\text { In situ hybridization } \\
\text { and Microarray }\end{array}$ & Hippocampus & $\begin{array}{l}1,3,14 \text { and } \\
56 \text { days }\end{array}$ & $\begin{array}{c}\text { Contralateral DG and } \\
\text { CA3: Significant increase } \\
\text { at day } 1,3 \text {, and } 14 \text { but not } \\
\text { at day } 56 \text {. } \\
\text { Ipsilateral/ contralateral } \\
\text { ratio of BDNF mRNA did } \\
\text { not differ from levels in } \\
\text { sham until } 8 \text { weeks } \\
\text { following injury }\end{array}$ & Not performed \\
\hline
\end{tabular}


Table A2. Cont.

\begin{tabular}{|c|c|c|c|c|c|c|c|c|}
\hline $\begin{array}{l}\text { BDNF Animal } \\
\text { Studies }\end{array}$ & $\mathbf{N}=$ & Animal & $\begin{array}{l}\text { Trauma } \\
\text { Model }\end{array}$ & $\begin{array}{c}\text { BDNF } \\
\text { Analysis }\end{array}$ & $\begin{array}{c}\text { Site of } \\
\text { Analysis }\end{array}$ & $\begin{array}{c}\text { Date of } \\
\text { Analysis }\end{array}$ & BDNF Expression & Functional Tests \\
\hline $\begin{array}{l}\text { (Kobori et al. } \\
\text { 2002) [70] }\end{array}$ & $10 /$ group & Mouse & CCI & $\begin{array}{l}\text { RNA Microarray } \\
\text { and real-time PCR }\end{array}$ & Cortex & $\begin{array}{l}2 \mathrm{~h}, 6 \mathrm{~h}, 24 \mathrm{~h}, \\
3 \text { days and } \\
14 \text { days }\end{array}$ & $\begin{array}{c}\text { Increased at } 2 \mathrm{~h}, 6 \mathrm{~h}, 24 \mathrm{~h}, \\
\text { decreased at } 3 \text { days, } \\
14 \text { days. }\end{array}$ & Not performed \\
\hline $\begin{array}{l}\text { (Wang et al. } \\
\text { 2018) [123] }\end{array}$ & $\begin{array}{l}\text { 12/group, } \\
\text { 6/group for } \\
\text { western }\end{array}$ & Mouse & $\begin{array}{l}\text { Blunt weight } \\
\text { drop }\end{array}$ & Western blot & $\begin{array}{c}\text { Homogenized } \\
\text { hippocampal } \\
\text { tissues }\end{array}$ & 21 days & $\begin{array}{c}\text { Decreased by trauma, } \\
\text { increased by treatment at } \\
\text { all timepoints }\end{array}$ & $\begin{array}{c}\text { Morris Water } \\
\text { Maze, step-down } \\
\text { test }\end{array}$ \\
\hline $\begin{array}{l}\text { (Umschweif } \\
\text { et al. 2014) [124] }\end{array}$ & $6-9 /$ group & Mouse & $\begin{array}{l}\text { Closed head } \\
\text { injury }\end{array}$ & Western blot & $\begin{array}{l}\text { Cortex and } \\
\text { subcortical } \\
\text { regions }\end{array}$ & $24 \mathrm{~h}$ & $\begin{array}{l}\text { No sham. Increased } \\
\text { by treatment. }\end{array}$ & $\begin{array}{c}\text { Neurological } \\
\text { Severity Score } \\
\text { and Novel Object } \\
\text { Recognition }\end{array}$ \\
\hline $\begin{array}{c}\text { (Ji et al. 2017) } \\
\text { [77] }\end{array}$ & $7 /$ group & Mouse & $\begin{array}{l}\text { Blunt weight } \\
\text { drop }\end{array}$ & Western blot & Cortex & 7 days & $\begin{array}{l}\text { Decreased by trauma, } \\
\text { increased by treatment }\end{array}$ & $\begin{array}{l}\text { Neurological } \\
\text { Severity Score, } \\
\text { rotarod, object } \\
\text { recognition, } \\
\text { Y-maze } \\
\end{array}$ \\
\hline $\begin{array}{l}\text { (Umschweif } \\
\text { et al., 2014) } \\
\text { [125] }\end{array}$ & 6/grp & Mouse & $\mathrm{CHI}$ & Western blot & $\begin{array}{c}\text { Frontal } \\
\text { segments of } \\
\text { injured } \\
\text { hemisphere }\end{array}$ & 6,24 and $72 \mathrm{~h}$ & Increased by treatment & $\begin{array}{l}\text { Neurological } \\
\text { severity score } \\
\text { and novel object } \\
\text { recognition Test }\end{array}$ \\
\hline $\begin{array}{l}\text { (Feng et al. } \\
\text { 2017) [81] }\end{array}$ & $5 /$ group & Rat & $\begin{array}{l}\text { Blunt weight } \\
\text { drop }\end{array}$ & $\begin{array}{l}\text { Western blot and } \\
\text { immunochemistry }\end{array}$ & Cortex & 14 days & $\begin{array}{l}\text { Not altered by trauma, } \\
\text { increased by treatment }\end{array}$ & $\begin{array}{l}\text { Mॅodified } \\
\text { Neurological } \\
\text { Severity Score, } \\
\text { rotarod }\end{array}$ \\
\hline $\begin{array}{c}\text { (Wu et al. 2011) } \\
{[61]}\end{array}$ & $5 /$ group & Rat & $\begin{array}{l}\text { Fluid } \\
\text { percussion } \\
\text { injury }\end{array}$ & Western blot & Hippocampus & Not specified & $\begin{array}{l}\text { Decreased by trauma, } \\
\text { increased by treatment }\end{array}$ & $\begin{array}{c}\text { Beam walking } \\
\text { test }\end{array}$ \\
\hline $\begin{array}{l}\text { (Rich et al. } \\
\text { 2010) [94] }\end{array}$ & $3 /$ group & Rat & $\begin{array}{l}\text { Blunt weight } \\
\text { drop }\end{array}$ & Western blot & $\begin{array}{r}\text { Site of injury, } \\
\text { hippocampus }\end{array}$ & $24 \mathrm{~h}$ & $\begin{array}{c}\text { No sham, increased } \\
\text { by treatment }\end{array}$ & $\begin{array}{c}\text { Morris Water } \\
\text { Maze }\end{array}$ \\
\hline $\begin{array}{c}\text { (Lee et al. 2012) } \\
\text { [126] }\end{array}$ & 4/group & Rat & $\begin{array}{l}\text { Blunt weight } \\
\text { drop }\end{array}$ & $\begin{array}{l}\text { In situ hybridization } \\
\text { and immunostaining }\end{array}$ & Hippocampus & $\begin{array}{c}0,2,4,12 \text { and } \\
24 \mathrm{~h}\end{array}$ & $\begin{array}{c}\text { Increased by trauma } \\
\text { (peaked at } 12 \mathrm{~h} \text { ), } \\
\text { increased by treatment at } \\
\text { all timepoints }\end{array}$ & Not performed \\
\hline $\begin{array}{c}\text { (Gu et al. 2014) } \\
\text { [127] }\end{array}$ & $\begin{array}{l}7 \text { for } \\
\text { Western } \\
\text { blot }\end{array}$ & Mouse & $\begin{array}{l}\text { Convex tip } \\
\text { impact }\end{array}$ & Western blot & Hippocampus & 20 days & $\begin{array}{l}\text { Decreased by trauma, } \\
\text { increased by treatment }\end{array}$ & $\begin{array}{l}\text { Morris Water } \\
\text { Maze }\end{array}$ \\
\hline $\begin{array}{l}\text { (Griesbach et al. } \\
\text { 2009) [48] }\end{array}$ & 6/group & Rat & CCI & Real-time PCR & Hippocampus & 10 days & $\begin{array}{l}\text { Decreased by trauma in } \\
\text { ipsilateral hippocampus, } \\
\text { no differences in } \\
\text { contralateral } \\
\text { hippocampus between } \\
\text { injured and sham }\end{array}$ & $\begin{array}{l}\text { Morris Water } \\
\text { Maze }\end{array}$ \\
\hline $\begin{array}{c}\text { (Agrawal et al. } \\
\text { 2014) [99] }\end{array}$ & $3 /$ group & Rat & FPI & Immunoblotting & Cortex & 7 days & $\begin{array}{l}\text { Decreased by trauma, } \\
\text { increased by treatment }\end{array}$ & $\begin{array}{c}\text { Elevated plus } \\
\text { maze }\end{array}$ \\
\hline $\begin{array}{c}\text { (Wu et al. 2006) } \\
\text { [53] }\end{array}$ & $8 /$ group & Rat & FPI & ELISA & Hippocampus & Not specified & $\begin{array}{l}\text { Decreased by trauma, } \\
\text { increased by treatment }\end{array}$ & $\begin{array}{c}\text { Morris water } \\
\text { maze }\end{array}$ \\
\hline $\begin{array}{l}\text { (Griesbach et al. } \\
\text { 2012) [63] }\end{array}$ & $\begin{array}{l}\text { 11- } \\
23 \text { /group }\end{array}$ & Rat & FPI & $\begin{array}{l}\text { Western blot and } \\
\text { ELISA }\end{array}$ & Hippocampus & 11 days & $\begin{array}{c}\text { Not altered by trauma, } \\
\text { not altered by treatment. } \\
\text { Although increased by } \\
\text { treatment in } \\
\text { non-injured group }\end{array}$ & Not performed \\
\hline $\begin{array}{l}\text { (Zhao et al. } \\
\text { 2017) [82] }\end{array}$ & $5 /$ group & Mouse & $\mathrm{CCI}$ & Western blot & $\begin{array}{l}\text { Pericontusion } \\
\text { tissue }\end{array}$ & 21 days & $\begin{array}{l}\text { Not altered by trauma, } \\
\text { increased by treatment }\end{array}$ & $\begin{array}{l}\text { Adhesive dot } \\
\text { removal test, } \\
\text { corner test, home } \\
\text { cage behavioral } \\
\text { test, cylinder test, } \\
\text { forced swim test, } \\
\text { open field test }\end{array}$ \\
\hline $\begin{array}{l}\text { (Yoon et al. } \\
\text { 2016) [128] }\end{array}$ & $12 /$ group & Rat & FPI & Immunohistochemistry & $\begin{array}{l}\text { Cortex and } \\
\text { hippocampus }\end{array}$ & 14 and 21 days & $\begin{array}{l}\text { No sham. Increased by } \\
\text { treatment in ipsilateral } \\
\text { hippocampus and cortex }\end{array}$ & $\begin{array}{l}\text { Rotarod, Barnes } \\
\text { Maze }\end{array}$ \\
\hline $\begin{array}{l}\text { (Deng et al. } \\
\text { 2018) [102] }\end{array}$ & $10 /$ group & Rat & $\begin{array}{l}\text { Electronic } \\
\text { brain injury } \\
\text { instrument }\end{array}$ & Immunohistochemistry & $\begin{array}{l}\text { Peri-injured } \\
\text { area }\end{array}$ & 28 days & $\begin{array}{c}\text { No sham, increased by } \\
\text { treatment }\end{array}$ & $\begin{array}{l}\text { Morris water } \\
\text { maze }\end{array}$ \\
\hline $\begin{array}{l}\text { (Liraz- } \\
\text { Zaltsman et al. } \\
\text { 2018) [129] }\end{array}$ & $3 /$ group & Mouse & $\begin{array}{l}\text { Closed head } \\
\text { injury }\end{array}$ & Immunohistochemistry & $\begin{array}{l}\text { Cortex and } \\
\text { hippocampus }\end{array}$ & 42 days & $\begin{array}{l}\text { No sham, increased } \\
\text { by treatment }\end{array}$ & $\begin{array}{l}\text { Neurological } \\
\text { severity score, } \\
\text { Novel object } \\
\text { recognition, } \\
\text { Y-maze, Barnes } \\
\text { maze, staircase } \\
\text { test } \\
\end{array}$ \\
\hline $\begin{array}{l}\text { (Gatson et al. } \\
\text { 2012) [130] }\end{array}$ & $\begin{array}{l}6 \text { for } \\
\text { control, } 8 \\
\text { for sham, } 10 \\
\text { for placebo, } \\
\text { and } 9 \text { for } \\
\text { estrone } \\
\end{array}$ & Rat & $\begin{array}{l}\text { Benchmark } \\
\text { Stereotaxic } \\
\text { Impactor }\end{array}$ & Immunohistochemistry & Cortex & $72 \mathrm{~h}$ & $\begin{array}{c}\text { No sham, increased } \\
\text { by treatment }\end{array}$ & Not performed \\
\hline $\begin{array}{c}\text { (Wu et al. 2013) } \\
{[64]}\end{array}$ & 5-6/group & Rat & FPI & Western blot & Hippocampus & 7 days & $\begin{array}{l}\text { Decreased by trauma, } \\
\text { increased by treatment }\end{array}$ & $\begin{array}{l}\text { Morris water } \\
\text { maze, Barnes } \\
\text { maze }\end{array}$ \\
\hline $\begin{array}{l}\text { (Chytrova et al. } \\
\text { 2008) [62] }\end{array}$ & $6 /$ group & Rat & FPI & Immunohistochemistry & Hippocampus & 10 days & $\begin{array}{l}\text { Decreased by trauma, } \\
\text { increased by treatment }\end{array}$ & Not performed \\
\hline $\begin{array}{l}\text { (Chou et al. } \\
\text { 2018) [69] }\end{array}$ & 10/group & Rat & FPI & Western blot & $\begin{array}{l}\text { Cortex and } \\
\text { hippocampus }\end{array}$ & 28 days & $\begin{array}{l}\text { Decreased by trauma, } \\
\text { increased by treatment }\end{array}$ & $\begin{array}{c}\text { Passive } \\
\text { avoidance test } \\
\text { and Y-maze }\end{array}$ \\
\hline $\begin{array}{l}\text { (Griesbach et al. } \\
\text { 2009) [67] }\end{array}$ & $8 /$ grp & Rat & FPI & Western blot & Hippocampus & 21 days & $\begin{array}{l}\text { Not altered by trauma, } \\
\text { increased by treatment }\end{array}$ & $\begin{array}{l}\text { Morris water } \\
\text { maze }\end{array}$ \\
\hline $\begin{array}{l}\text { (Crupi et al. } \\
\text { 2013) [73] }\end{array}$ & $5 /$ group & Mouse & CCI & Western blot & $\begin{array}{c}\text { Cortex and } \\
\text { hippocampus }\end{array}$ & $24 \mathrm{~h}$ & $\begin{array}{l}\text { Decreased by trauma, } \\
\text { increased by treatment }\end{array}$ & $\begin{array}{c}\text { Swing test and } \\
\text { rotarod }\end{array}$ \\
\hline
\end{tabular}


Table A2. Cont.

\begin{tabular}{|c|c|c|c|c|c|c|c|c|}
\hline $\begin{array}{l}\text { BDNF Animal } \\
\text { Studies }\end{array}$ & $\mathbf{N}=$ & Animal & $\begin{array}{l}\text { Trauma } \\
\text { Model }\end{array}$ & $\begin{array}{c}\text { BDNF } \\
\text { Analysis }\end{array}$ & $\begin{array}{c}\text { Site of } \\
\text { Analysis }\end{array}$ & $\begin{array}{c}\text { Date of } \\
\text { Analysis }\end{array}$ & BDNF Expression & Functional Tests \\
\hline $\begin{array}{l}\text { (Grundy et al. } \\
\text { 2000) [131] }\end{array}$ & $\begin{array}{l}34 \text { for TBI, } \\
13 \text { for sham }\end{array}$ & Rat & FPI & In situ hybridization & Hippocampus & $4 \mathrm{~h}$ & $\begin{array}{c}\text { Increased by trauma, } \\
\text { further increased by } \\
\text { treatment }\end{array}$ & Not performed \\
\hline $\begin{array}{l}\text { (Song et al. } \\
\text { 2016) [132] }\end{array}$ & $20 /$ grp & Mouse & CCI & ELISA & $\begin{array}{l}\text { Cortex and } \\
\text { hippocampus }\end{array}$ & 3,7 and 14 days & $\begin{array}{c}\text { Sham not presented, } \\
\text { increased by treatment at } \\
\text { day } 3 \text { ipsilaterally and } \\
\text { day } 7 \text { contralaterally }\end{array}$ & $\begin{array}{l}\text { Radial Arm } \\
\text { Water Maze and } \\
\text { rotarod }\end{array}$ \\
\hline $\begin{array}{l}\text { (Dobrachinski } \\
\text { et al. 2019) [50] }\end{array}$ & $5 /$ group & Rat & FPI & Quantitative PCR & Hippocampus & 21 days & $\begin{array}{l}\text { Decreased by trauma, } \\
\text { increased by treatment }\end{array}$ & $\begin{array}{c}\text { Locomotor } \\
\text { behavior, } \\
\text { Elevated plus } \\
\text { maze, Inhibitory } \\
\text { avoidance task, } \\
\text { and object } \\
\text { recognition test }\end{array}$ \\
\hline $\begin{array}{l}\text { (Matzilevich } \\
\text { et al. 2002) [46] }\end{array}$ & $10 /$ group & Rat & CCI & $\begin{array}{l}\text { Microarray, northern } \\
\text { blot and immunohis- } \\
\text { tochemistry }\end{array}$ & Hippocampus & $5 \mathrm{~h}$ and $26 \mathrm{~h}$ & $\begin{array}{l}\text { Not altered at } 5 \mathrm{~h}, \\
\text { increased at } 26 \mathrm{~h}\end{array}$ & Not performed \\
\hline $\begin{array}{l}\text { (Wang et al. } \\
\text { 2014) [44] }\end{array}$ & 4/group & Rat & FPI & $\begin{array}{l}\text { Quantitative } \\
\text { real-time PCR }\end{array}$ & Hippocampus & $3 \mathrm{~h}$ and $6 \mathrm{~h}$ & $\begin{array}{c}\text { Increased by trauma, } \\
\text { decreased by treatment in } \\
\text { ipsilateral hippocampus } \\
\text { at } 3 \mathrm{~h} \text { but not altered in } \\
\text { contralateral }\end{array}$ & Not performed \\
\hline $\begin{array}{l}\text { (Hou et al. } \\
\text { 2012) [56] }\end{array}$ & $12 /$ group & Rat & FPI & ELISA & $\mathrm{HC}$ & 7 days & $\begin{array}{l}\text { Decreased by trauma, } \\
\text { increased by treatment }\end{array}$ & $\begin{array}{l}\text { Morris water } \\
\text { maze }\end{array}$ \\
\hline $\begin{array}{l}\text { (Algamal et al. } \\
\text { 2019) [133] }\end{array}$ & $15 /$ group & Mouse & $\begin{array}{l}\text { Closed head } \\
\text { injury }\end{array}$ & ELISA & $\mathrm{HC}$ & 3 months & Not altered by trauma & $\begin{array}{l}\text { Contextual and } \\
\text { cued fear test, } \\
\text { open field, } \\
\text { elevated plus } \\
\text { maze, forced } \\
\text { swim, radial arm } \\
\text { water maze and } \\
\text { three chamber } \\
\text { test }\end{array}$ \\
\hline $\begin{array}{l}\text { (Yang et al. } \\
1996) \text { [47] }\end{array}$ & $3 /$ group & Rat & CCI & In situ hybridization & $\begin{array}{c}\text { Cortex and } \\
\text { hippocampus }\end{array}$ & 1,3 , and $5 \mathrm{~h}$ & Increased by trauma & $\begin{array}{c}\text { Postural } \\
\text { somatomotor } \\
\text { reflexes }\end{array}$ \\
\hline $\begin{array}{l}\text { (Mahmood et al. } \\
\text { 2004) [100] }\end{array}$ & 9/group & Rat & $\begin{array}{l}\text { Pneumatic } \\
\text { piston } \\
\text { compression }\end{array}$ & $\begin{array}{l}\text { Immunohistochemistry } \\
\text { and ELISA }\end{array}$ & Periinjured area & 2,5 and 8 days & $\begin{array}{l}\text { No sham. Increased by } \\
\text { treatment at day } 8 \text { but no } \\
\text { significantly altered at } \\
\text { day } 2 \text { or } 5\end{array}$ & $\begin{array}{l}\text { Modified } \\
\text { neurological } \\
\text { severity score }\end{array}$ \\
\hline $\begin{array}{c}\text { (Ko et al. 2018) } \\
{[134]}\end{array}$ & $10 /$ grp & Rat & $\begin{array}{l}\text { Stereotaxic } \\
\text { Impactor }\end{array}$ & Western blot & Hippocampus & 11 weeks & $\begin{array}{l}\text { Increased by trauma, } \\
\text { decreased by treatment }\end{array}$ & $\begin{array}{l}\text { Radial 8-arm } \\
\text { maze }\end{array}$ \\
\hline $\begin{array}{l}\text { (Mahmood et al. } \\
\text { 2009) [135] }\end{array}$ & $8 /$ group & Rat & CCI & ELISA & $\begin{array}{c}\text { Cortex and } \\
\text { hippocampus }\end{array}$ & 3 months & $\begin{array}{c}\text { No sham, increased by } \\
\text { treatment. }\end{array}$ & $\begin{array}{c}\text { Modified } \\
\text { neurological } \\
\text { severity score }\end{array}$ \\
\hline $\begin{array}{l}\text { (Mahmood et al. } \\
\text { 2006) [101] }\end{array}$ & $10 /$ grp & Rat & CCI & ELISA & $\begin{array}{c}\text { Contralateral } \\
\text { and ipsilateral } \\
\text { hemispheres }\end{array}$ & 3 months & $\begin{array}{c}\text { No sham. Increased by } \\
\text { treatment. }\end{array}$ & $\begin{array}{l}\text { Neurological } \\
\text { severity score }\end{array}$ \\
\hline $\begin{array}{l}\text { Xuan et al. } \\
\text { 2015) [136] }\end{array}$ & $10 /$ group & Mouse & $\mathrm{CCI}$ & $\begin{array}{c}\text { Immunofluorescence } \\
\text { staining }\end{array}$ & $\begin{array}{c}\text { Cortex and } \\
\text { hippocampus }\end{array}$ & 7 and 28 days & $\begin{array}{l}\text { Not altered by trauma, } \\
\text { increased by treatment }\end{array}$ & $\begin{array}{l}\text { Neurological } \\
\text { severity score }\end{array}$ \\
\hline $\begin{array}{c}\text { (Wu et al. 2016) } \\
\text { [74] }\end{array}$ & $12 /$ grp & Rat & $\mathrm{CCI}$ & Western blot & Cortex & $24 \mathrm{~h}$ & $\begin{array}{l}\text { Decreased by trauma, } \\
\text { increased by treatment }\end{array}$ & $\begin{array}{l}\text { Neurological } \\
\text { severity score }\end{array}$ \\
\hline $\begin{array}{l}\text { (Colak et al. } \\
\text { 2012) [43] }\end{array}$ & $15 /$ grp & Rat & $\mathrm{CHI}$ & $\begin{array}{l}\text { Quantitative } \\
\text { real-time PCR and } \\
\text { whole genome } \\
\text { microarray }\end{array}$ & $\begin{array}{l}\text { Frontal and } \\
\text { parietal brain } \\
\text { tissues }\end{array}$ & 1,12 and $48 \mathrm{~h}$ & $\begin{array}{l}\text { Increased at } 1 \mathrm{~h} \text { and at } 12 \\
\mathrm{~h} \text { compared to control } \\
\text { group, decreased at } 48 \mathrm{~h} \text {. }\end{array}$ & Not performed \\
\hline $\begin{array}{l}\text { (Shah et al. } \\
\text { 2006) [137] }\end{array}$ & 4/group & Mouse & FPI & Real-time PCR & Hippocampus & 1 day & Not altered by trauma & Not performed \\
\hline $\begin{array}{l}\text { (Esenaliev et al. } \\
\text { 2018) [138] }\end{array}$ & $3-4 /$ grp & Rat & Blast injury & $\begin{array}{l}\text { Quantitative } \\
\text { real-time PCR }\end{array}$ & $\begin{array}{l}\text { Cortex and } \\
\text { hippocampus }\end{array}$ & 3 and 7 days & $\begin{array}{l}\text { Decreased by trauma at } 3 \\
\text { in cortex and at } 7 \text { days in } \\
\text { the hippocampus. } \\
\text { Increased by treatment. }\end{array}$ & $\begin{array}{c}\text { Beam balance } \\
\text { test }\end{array}$ \\
\hline $\begin{array}{l}\text { (Xiong et al. } \\
\text { 2018) [79] }\end{array}$ & 5-8/grp & Rat & $\begin{array}{l}\text { Blunt weight } \\
\text { drop }\end{array}$ & $\begin{array}{l}\text { Immunofluorescent } \\
\text { staining and ELISA }\end{array}$ & $\begin{array}{l}\text { Pericontusional } \\
\text { regions }\end{array}$ & 7 days & $\begin{array}{l}\text { Decreased by trauma, } \\
\text { increased by treatment }\end{array}$ & $\begin{array}{l}\text { Neurological } \\
\text { severity score } \\
\text { and rotarod }\end{array}$ \\
\hline $\begin{array}{l}\text { (Bhatt et al. } \\
\text { 2017) [139] }\end{array}$ & $6 /$ grp & Rat & $\begin{array}{l}\text { Blunt weight } \\
\text { drop }\end{array}$ & ELISA & Whole brain & 28 days & $\begin{array}{l}\text { Decreased by trauma, } \\
\text { increased by treatment }\end{array}$ & $\begin{array}{c}\text { Open field, } \\
\text { elevated plus } \\
\text { maze, sucrose } \\
\text { consumption test } \\
\text { and marble } \\
\text { burying test } \\
\end{array}$ \\
\hline $\begin{array}{l}\text { (Chandrasekar } \\
\text { et al. 2018) [95] }\end{array}$ & $\begin{array}{c}\text { Not } \\
\text { available }\end{array}$ & Mouse & $\begin{array}{l}\text { Blunt weight } \\
\text { drop }\end{array}$ & Real-time PCR & Hippocampus & $1 \mathrm{~h}$ and $3 \mathrm{~h}$ & $\begin{array}{l}\text { Increased by trauma, } \\
\text { decreased by treatment }\end{array}$ & $\begin{array}{l}\text { Neurological } \\
\text { severity score }\end{array}$ \\
\hline $\begin{array}{l}\text { (Gugliandolo } \\
\text { et al. 2018) [75] }\end{array}$ & $10 /$ grp & Mouse & $\mathrm{CCI}$ & $\begin{array}{l}\text { Immunohistochemistry } \\
\text { and } \\
\text { immunofluorescence }\end{array}$ & $\begin{array}{l}\text { Perilesional } \\
\text { tissue }\end{array}$ & 1 day & $\begin{array}{l}\text { Decreased by trauma, } \\
\text { increased by treatment }\end{array}$ & Not performed \\
\hline $\begin{array}{l}\text { (Shin et al. } \\
\text { 2016) [93] }\end{array}$ & $10 /$ grp & Rat & $\begin{array}{l}\text { Stereotaxic } \\
\text { Impactor }\end{array}$ & Western blot & Hippocampus & 41 days & $\begin{array}{l}\text { Deceased by trauma, } \\
\text { increased by treatment }\end{array}$ & $\begin{array}{c}\text { Step-down } \\
\text { avoidance test } \\
\text { and radial 8-arm } \\
\text { maze test }\end{array}$ \\
\hline $\begin{array}{l}\text { (Sönmez et al. } \\
\text { 2015) [140] }\end{array}$ & $7 /$ grp & Rat & $\begin{array}{l}\text { Percussion } \\
\text { trauma } \\
\text { model in } \\
\text { immature } \\
\text { rats }\end{array}$ & Immunohistochemistry & Hippocampus & 4 days & $\begin{array}{l}\text { Decreased by trauma, } \\
\text { increased by treatment }\end{array}$ & $\begin{array}{l}\text { Elevated plus } \\
\text { maze and novel } \\
\text { object } \\
\text { recognition }\end{array}$ \\
\hline
\end{tabular}


Table A2. Cont.

\begin{tabular}{|c|c|c|c|c|c|c|c|c|}
\hline $\begin{array}{l}\text { BDNF Animal } \\
\text { Studies }\end{array}$ & $\mathbf{N}=$ & Animal & $\begin{array}{l}\text { Trauma } \\
\text { Model }\end{array}$ & $\begin{array}{c}\text { BDNF } \\
\text { Analysis }\end{array}$ & $\begin{array}{c}\text { Site of } \\
\text { Analysis }\end{array}$ & $\begin{array}{c}\text { Date of } \\
\text { Analysis }\end{array}$ & BDNF Expression & Functional Tests \\
\hline $\begin{array}{l}\text { (Shang et al. } \\
\text { 2014) [141] }\end{array}$ & 8/group & Mouse & CCI & Western blot & Hippocampus & $\begin{array}{l}1,3,7,14 \text { and } \\
21 \text { days }\end{array}$ & $\begin{array}{l}\text { Decreased by trauma, } \\
\text { increased by treatment }\end{array}$ & $\begin{array}{c}\text { Open field test, } \\
\text { beam walk and } \\
\text { Morris water } \\
\text { maze }\end{array}$ \\
\hline $\begin{array}{l}\text { (Mao et al. } \\
\text { 2015) [65] }\end{array}$ & $\begin{array}{l}24 \text { for TBI, } \\
20 \text { for sham }\end{array}$ & Rat & $\mathrm{CCI}$ & ELISA & Hippocampus & 14 days & $\begin{array}{l}\text { Decreased by trauma, } \\
\text { increased by treatment }\end{array}$ & $\begin{array}{l}\text { Morris water } \\
\text { maze }\end{array}$ \\
\hline $\begin{array}{l}\text { (Ghadiri et al. } \\
\text { 2019) [142] }\end{array}$ & 14 /group & Rat & Weight drop & Western blot & Hippocampus & 15 days & $\begin{array}{c}\text { No sham, increased by } \\
\text { treatment }\end{array}$ & $\begin{array}{c}\text { Modified } \\
\text { neurological } \\
\text { severity score } \\
\text { and tonic-clonic } \\
\text { seizure score }\end{array}$ \\
\hline $\begin{array}{l}\text { (Cekic et al. } \\
\text { 2012) [88] }\end{array}$ & $18 /$ group & Rat & CCI & Western blot & $\begin{array}{l}\text { Perilesional } \\
\text { tissue }\end{array}$ & 1,3 and 7 days & $\begin{array}{l}\text { Increased by trauma, } \\
\text { decreased by treatment at } \\
\text { day } 1 \text {. Not altered by } \\
\text { trauma, decreased by } \\
\text { treatment at day } 3 \text {. } \\
\text { Increased by trauma, not } \\
\text { altered by treatment at } \\
\text { day } 7 \text {. }\end{array}$ & $\begin{array}{l}\text { Spontaneous } \\
\text { locomotor } \\
\text { activity and } \\
\text { behavioral data }\end{array}$ \\
\hline $\begin{array}{l}\text { (Nagamoto- } \\
\text { Combs et al. } \\
\text { 2007) [89] }\end{array}$ & $\begin{array}{l}\text { 1/timepoint, } \\
(3 \text { total })\end{array}$ & $\begin{array}{l}\text { Rhesus } \\
\text { mon- } \\
\text { key }\end{array}$ & $\begin{array}{l}\text { Aspiration } \\
\text { injury }\end{array}$ & Immunohistochemistry & Cortex & $\begin{array}{l}1,6 \text {, and } \\
12 \text { months }\end{array}$ & $\begin{array}{l}\text { Non-detectable } \\
\text { BDNF-immunoreactivity } \\
\text { in sham. } \\
\text { Increased } \\
\text { BDNF-immunoreactivity } \\
\text { at all time points, } \\
\text { especially at } 6 \text { months. }\end{array}$ & $\begin{array}{c}\text { Modified } \\
\text { monkey } \\
\text { assessment panel }\end{array}$ \\
\hline $\begin{array}{c}\text { (Ma et al. 2018) } \\
{[85]}\end{array}$ & $14 /$ group & Rat & $\mathrm{CCI}$ & $\begin{array}{l}\text { Western blot and im- } \\
\text { munohistochemistry }\end{array}$ & Cortex & 30 days & $\begin{array}{l}\text { Decreased by trauma, } \\
\text { increased by treatment }\end{array}$ & $\begin{array}{c}\text { Modified } \\
\text { neurological } \\
\text { severity score } \\
\text { and Object } \\
\text { Recognition Test }\end{array}$ \\
\hline $\begin{array}{l}\text { (Griesbach et al. } \\
\text { 2014) [91] }\end{array}$ & $\begin{array}{l}29 \text { for TBI, } \\
28 \text { for sham }\end{array}$ & Rat & FPI & ELISA & Hippocampus & 39 days & $\begin{array}{l}\text { Decreased by trauma, } \\
\text { increased by treatment }\end{array}$ & Activity level \\
\hline $\begin{array}{l}\text { (Oyesiku et al. } \\
\text { 1999) [143] }\end{array}$ & $6-9 /$ group & Rat & $\begin{array}{l}\text { Pneumatic } \\
\text { piston } \\
\text { compression }\end{array}$ & Northern blot & Lesion site & 12,24 and $36 \mathrm{~h}$ & $\begin{array}{c}\text { Increased by trauma at } 12 \\
\text { and } 24 \mathrm{~h} \text {, not altered at } \\
36 \mathrm{~h} \text { at lesion site and } \\
\text { remote site. }\end{array}$ & Not performed \\
\hline $\begin{array}{l}\text { (Gölz et al. } \\
\text { 2019) [144] }\end{array}$ & $\begin{array}{l}10 \text { for TBI, } 6 \\
\text { for sham }\end{array}$ & Mouse & CCI & Western blot & $\begin{array}{c}\text { Ipsilesional } \\
\text { brain quadrants }\end{array}$ & $72 \mathrm{~h}$ & $\begin{array}{l}\text { Not altered by trauma, } \\
\text { not altered by treatment }\end{array}$ & $\begin{array}{l}\text { Neurological } \\
\text { severity score }\end{array}$ \\
\hline $\begin{array}{l}\text { (Khan et al. } \\
\text { 2011) [49] }\end{array}$ & $\begin{array}{c}13 \text { for } \\
\text { control, } 30 \\
\text { for sham, } 28 \\
\text { or } 40 \text { for } \\
\text { treated }\end{array}$ & Rat & CCI & Immunohistochemistry & $\begin{array}{l}\text { Whole brain } \\
\text { sections }\end{array}$ & 14 days & $\begin{array}{l}\text { Decreased by trauma, } \\
\text { increased by treatment }\end{array}$ & Not performed \\
\hline $\begin{array}{l}\text { (Corne et al. } \\
\text { 2019) [90] }\end{array}$ & $6-8 / \operatorname{grp}$ & Mouse & CCI & $\begin{array}{l}\text { Quantitative } \\
\text { real-time PCR }\end{array}$ & $\begin{array}{l}\text { Whole brain } \\
\text { sections }\end{array}$ & 3 months & Decreased by trauma & $\begin{array}{c}\text { Fear } \\
\text { conditioning and } \\
\text { fear extinction, } \\
\text { elevated plus } \\
\text { maze, open field } \\
\text { test, Barnes maze } \\
\text { and } \\
\text { sensory-motor } \\
\text { skills }\end{array}$ \\
\hline $\begin{array}{l}\text { (Wang et al. } \\
\text { 2019) [105] }\end{array}$ & $10 /$ grp & Rat & $\begin{array}{l}\text { Blunt weight } \\
\text { drop }\end{array}$ & Immunofluorescence & $\begin{array}{l}\text { Perilesional } \\
\text { tissue }\end{array}$ & $\begin{array}{l}10,14 \text { and } \\
20 \text { days }\end{array}$ & $\begin{array}{c}\text { No sham, increased by } \\
\text { treatment }\end{array}$ & $\begin{array}{l}\text { Neurological } \\
\text { severity score }\end{array}$ \\
\hline $\begin{array}{l}\text { (Meng et al. } \\
\text { 2014) [80] }\end{array}$ & 4/group & Rat & CCI & $\begin{array}{l}\text { Western blot and im- } \\
\text { munohistochemistry }\end{array}$ & Cortex & 8 and 35 days & $\begin{array}{l}\text { Decreased by trauma, } \\
\text { increased by treatment }\end{array}$ & $\begin{array}{l}\text { Morris water } \\
\text { maze and } \\
\text { modified } \\
\text { neurological } \\
\text { severity score }\end{array}$ \\
\hline $\begin{array}{l}\text { (Cutler et al. } \\
\text { 2006) [145] }\end{array}$ & $10 /$ grp & Rat & $\begin{array}{l}\text { Pneumatic } \\
\text { cortical } \\
\text { contusion }\end{array}$ & Western blot & $\begin{array}{l}\text { Perilesional } \\
\text { tissue }\end{array}$ & 3 weeks & $\begin{array}{l}\text { Decreased by trauma, } \\
\text { increased by treatment }\end{array}$ & $\begin{array}{l}\text { Locomotor } \\
\text { activity and } \\
\text { somatosensory } \\
\text { neglect }\end{array}$ \\
\hline $\begin{array}{l}\text { (Tyagi et al. } \\
\text { 2014) [54] }\end{array}$ & 6/grp & Rat & FPI & Immunoblotting & Hippocampus & 7 days & $\begin{array}{l}\text { Decreased by trauma, } \\
\text { increased by treatment }\end{array}$ & $\begin{array}{c}\text { Elevated plus } \\
\text { maze }\end{array}$ \\
\hline $\begin{array}{l}\text { (Ignowski et al. } \\
\text { 2018) [96] }\end{array}$ & 3-4/group & Mouse & $\mathrm{CCI}$ & Immunohistochemistry & $\begin{array}{l}\text { Whole brain } \\
\text { lysates }\end{array}$ & $72 \mathrm{~h}$ & $\begin{array}{l}\text { Deceased by trauma, } \\
\text { increased by treatment. }\end{array}$ & $\begin{array}{l}\text { Beam walking } \\
\text { test, rotarod and } \\
\text { Barnes maze }\end{array}$ \\
\hline $\begin{array}{l}\text { (Mychasiuk } \\
\text { et al. 2016) [146] }\end{array}$ & $12 /$ grp & Rat & $\begin{array}{l}\text { Modified } \\
\text { weight drop } \\
\text { mTBI and } \\
\text { Lateral } \\
\text { impact mTBI }\end{array}$ & $\begin{array}{c}\text { Quantitative } \\
\text { real-time PCR }\end{array}$ & $\begin{array}{c}\text { Cortex and } \\
\text { hippocampus }\end{array}$ & 14 days & $\begin{array}{l}\text { No significant difference } \\
\text { between sham, weight } \\
\text { drop or lateral impact. } \\
\text { BDNF expression was } \\
\text { dependent on examined } \\
\text { brain region and } \\
\text { animal sex }\end{array}$ & $\begin{array}{c}\text { Time-to-right, } \\
\text { open field test, } \\
\text { elevated plus } \\
\text { maze, novel } \\
\text { context } \\
\text { mismatch and } \\
\text { forced swim test }\end{array}$ \\
\hline $\begin{array}{l}\text { (Shen et al. } \\
\text { 2013) [68] }\end{array}$ & $\begin{array}{l}10 \text { for } \\
\text { trauma, } 5 \\
\text { for sham }\end{array}$ & Rat & $\mathrm{CCI}$ & Western blot & Hippocampus & 26 days & $\begin{array}{l}\text { Not altered by trauma, } \\
\text { increased by treatment }\end{array}$ & $\begin{array}{c}\text { Neurologic } \\
\text { Deficit Scores } \\
\text { and Morris water } \\
\text { maze }\end{array}$ \\
\hline $\begin{array}{l}\text { (da Silva Fiorin } \\
\text { et al. 2016) [66] }\end{array}$ & $40 /$ grp & Rat & FPI & Western blot & Hippocampus & 1 and 15 days & $\begin{array}{l}\text { Not altered by trauma, } \\
\text { increased by treatment at } \\
\text { both timepoints. } 1 \\
15 \text { DPI. }\end{array}$ & $\begin{array}{l}\text { Neuroscore and } \\
\text { object } \\
\text { recognition test }\end{array}$ \\
\hline $\begin{array}{c}\text { (Qi et al. 2018) } \\
\text { [104] }\end{array}$ & $10 / g r p$ & Rat & CCI & $\begin{array}{c}\text { Quantitative } \\
\text { real-time PCR and } \\
\text { ELISA }\end{array}$ & Whole brain & $\begin{array}{l}7,14,21 \text { and } 28 \\
\text { days }\end{array}$ & $\begin{array}{c}\text { No sham, increased } \\
\text { by treatment }\end{array}$ & $\begin{array}{l}\text { Neurological } \\
\text { severity score }\end{array}$ \\
\hline
\end{tabular}


Table A2. Cont.

\begin{tabular}{|c|c|c|c|c|c|c|c|c|}
\hline $\begin{array}{l}\text { BDNF Animal } \\
\text { Studies }\end{array}$ & $\mathbf{N}=$ & Animal & $\begin{array}{l}\text { Trauma } \\
\text { Model }\end{array}$ & $\begin{array}{c}\text { BDNF } \\
\text { Analysis }\end{array}$ & $\begin{array}{c}\text { Site of } \\
\text { Analysis }\end{array}$ & $\begin{array}{c}\text { Date of } \\
\text { Analysis }\end{array}$ & BDNF Expression & Functional Tests \\
\hline $\begin{array}{l}\text { (Xing et al. } \\
\text { 2018) [147] }\end{array}$ & $3 /$ grp & Rat & $\begin{array}{l}\text { Modified } \\
\text { Marmarou } \\
\text { weight drop }\end{array}$ & $\begin{array}{l}\text { Quantitative } \\
\text { real-time PCR }\end{array}$ & $\begin{array}{l}\text { Ipsilateral } \\
\text { hemisphere }\end{array}$ & $\begin{array}{c}3 \mathrm{~h}, 6 \mathrm{~h}, 1 \text { day, } \\
3 \text { days and } \\
7 \text { days }\end{array}$ & $\begin{array}{l}\text { Not altered by trauma, } \\
\text { increased by treatment }\end{array}$ & Not performed \\
\hline $\begin{array}{c}\text { (Wu et al. 2011) } \\
\text { [61] }\end{array}$ & $12 /$ grp & Rat & FPI & Western blot & Hippocampus & 7 days & $\begin{array}{l}\text { Decreased by trauma, } \\
\text { increased by treatment. }\end{array}$ & $\begin{array}{l}\text { Morris water } \\
\text { maze }\end{array}$ \\
\hline $\begin{array}{l}\text { (Griesbach et al. } \\
\text { 2004) [78] }\end{array}$ & 4/grp & Rat & FPI & ELISA & Cortex & 7 days & $\begin{array}{l}\text { Not altered by trauma, } \\
\text { not altered by treatment }\end{array}$ & Beam-walk test \\
\hline $\begin{array}{l}\text { (Kim et al. 2010) } \\
\text { [103] }\end{array}$ & $\begin{array}{l}6 \text { for ELISA, } \\
2 \text { for } \\
\text { immunohis- } \\
\text { tochemistry }\end{array}$ & Rat & $\begin{array}{l}\text { Pneumatic } \\
\text { cortical } \\
\text { contusion }\end{array}$ & ELISA & $\begin{array}{c}\text { Ipsilateral } \\
\text { hemispheres }\end{array}$ & $2,8,15,29$ days & $\begin{array}{c}\text { Increased by trauma, } \\
\text { increased by treatment at } \\
\text { day } 2 \text { but not at day } 8,15 \\
\text { or } 29\end{array}$ & $\begin{array}{c}\text { Modified } \\
\text { neurological } \\
\text { severity score } \\
\text { and rotarod }\end{array}$ \\
\hline $\begin{array}{l}\text { (Griesbach et al. } \\
\text { 2007) [59] }\end{array}$ & $8 /$ grp & Rat & FPI & ELISA & Hippocampus & $\begin{array}{l}\text { 7, } 21 \text { and } \\
37 \text { days }\end{array}$ & $\begin{array}{c}\text { Not altered by trauma, } \\
\text { increased by treatment. } \\
\text { Dependent on timing of } \\
\text { exercise. }\end{array}$ & $\begin{array}{l}\text { Gross motor } \\
\text { impairments }\end{array}$ \\
\hline $\begin{array}{c}\text { (Su et al. 2017) } \\
{[76]}\end{array}$ & 6-7/grp & Mouse & CCI & $\begin{array}{l}\text { Western blot and im- } \\
\text { munohistochemistry }\end{array}$ & Cortex & 1 and 4 days & $\begin{array}{l}\text { Decreased by trauma, } \\
\text { increased by treatment at } \\
\text { day } 4 \text { but not day } 1 .\end{array}$ & Not performed \\
\hline $\begin{array}{l}\text { (Impellizzeri } \\
\text { et al. 2016) [148] }\end{array}$ & $5 /$ grp & Mouse & Chronic CCI & Immunohistochemistry & $\begin{array}{l}\text { Midbrain } \\
\text { samples }\end{array}$ & 30 days & Decreased by trauma. & $\begin{array}{c}\text { Open field, } \\
\text { Elevated plus } \\
\text { maze and Barnes } \\
\text { maze }\end{array}$ \\
\hline $\begin{array}{l}\text { (Boone et al. } \\
\text { 2012) [45] }\end{array}$ & $6 /$ grp & Rat & FPI & $\begin{array}{l}\text { Quantitative } \\
\text { real-time PCR }\end{array}$ & $\begin{array}{c}\text { Ipsilateral } \\
\text { hippocampus }\end{array}$ & 20 hours & $\begin{array}{l}\text { Decreased by trauma and } \\
\text { sham }\end{array}$ & $\begin{array}{l}\text { Locomotor } \\
\text { behavior }\end{array}$ \\
\hline $\begin{array}{l}\text { (Mahmood et al. } \\
\text { 2007) [149] }\end{array}$ & $5 /$ grp & Rat & CCI & ELISA & $\begin{array}{c}\text { Ipsilateral } \\
\text { hemisphere }\end{array}$ & 6 and $24 \mathrm{~h}$ & Increased by treatment & $\begin{array}{l}\text { Morris water } \\
\text { maze }\end{array}$ \\
\hline $\begin{array}{l}\text { (Portbury et al. } \\
\text { 2017) [98] }\end{array}$ & 5/grp & Mouse & $\mathrm{CCI}$ & Western blot & $\begin{array}{l}\text { Ipsilateral and } \\
\text { contralateral } \\
\text { cortex and } \\
\text { hippocampus }\end{array}$ & $\begin{array}{l}24 \mathrm{~h}, 72 \mathrm{~h}, \\
7 \text { days, } 14 \text { days } \\
\text { and } 28 \text { days }\end{array}$ & $\begin{array}{l}\text { Increased by treatment in } \\
\text { the contralateral cortex, } \\
\text { but not in the other } \\
\text { examined areas }\end{array}$ & $\begin{array}{l}\text { Morris water } \\
\text { maze and } \\
\text { Y-maze }\end{array}$ \\
\hline $\begin{array}{l}\text { (Chang et al. } \\
\text { 2019) [84] }\end{array}$ & $5 /$ grp & Swine & CCI & Western blot & $\begin{array}{c}\text { Cortical } \\
\text { sections } \\
\text { adjacent to the } \\
\text { injury. }\end{array}$ & 30 days & $\begin{array}{l}\text { Decreased by trauma, } \\
\text { increased by treatment }\end{array}$ & $\begin{array}{l}\text { neurological } \\
\text { severity score }\end{array}$ \\
\hline $\begin{array}{c}\text { (Wu et al. 2010) } \\
\text { [55] }\end{array}$ & $6-8 / \operatorname{grp}$ & Rat & FPI & ELISA & $\begin{array}{c}\text { ipsilateral } \\
\text { hippocampus }\end{array}$ & 7 days dietary & $\begin{array}{l}\text { Decreased by trauma, } \\
\text { increased by treatment }\end{array}$ & $\begin{array}{l}\text { Morris water } \\
\text { maze }\end{array}$ \\
\hline $\begin{array}{l}\text { (Griesbach et al. } \\
\text { 2004) [58] }\end{array}$ & $\begin{array}{l}\mathrm{FPI}=89 \\
\text { sham }=72\end{array}$ & Rat & FPI & $\begin{array}{l}\text { ELISA and immuno- } \\
\text { histochemistry }\end{array}$ & $\begin{array}{l}\text { Ipsilateral and } \\
\text { contralateral } \\
\text { hippocampus }\end{array}$ & 7 and 21 days & $\begin{array}{l}\text { Not altered by trauma. } \\
\text { Not altered by treatment } \\
\text { ipsilaterally at day } 7, \text { but } \\
\text { increased by treatment } \\
\text { ipsilaterally at day } 21 . \\
\text { Decreased by treatment } \\
\text { contralaterally at day } 7 \\
\text { but increased } \\
\text { contralaterally at day } 21\end{array}$ & Water maze \\
\hline $\begin{array}{l}\text { (Zhao et al. } \\
\text { 2015) [71] }\end{array}$ & $5-8 /$ grp & Mouse & CCI & $\begin{array}{l}\text { Quantitative } \\
\text { real-time PCR }\end{array}$ & $\begin{array}{l}\text { Ipsilateral } \\
\text { cortex }\end{array}$ & 24 hours & $\begin{array}{l}\text { Not altered by trauma, } \\
\text { increased by treatment }\end{array}$ & $\begin{array}{l}\text { Beam walking, } \\
\text { Morris water } \\
\text { maze, } \\
\text { tail-suspension, } \\
\text { open field test, } \\
\text { and novel object } \\
\text { recognition test } \\
\end{array}$ \\
\hline $\begin{array}{l}\text { (Cheng et al. } \\
\text { 2015) [72] }\end{array}$ & $6 /$ grp & Rat & Weight drop & $\begin{array}{l}\text { Western blot and } \\
\text { quantitative } \\
\text { real-time PCR }\end{array}$ & $\begin{array}{l}\text { Ipsilateral } \\
\text { perilesional } \\
\text { cortex and } \\
\text { subcortical } \\
\text { regions. }\end{array}$ & 14 days & Increased by treatment & $\begin{array}{c}\text { Modified } \\
\text { neurological } \\
\text { severity score, } \\
\text { Morris water } \\
\text { maze, and novel } \\
\text { object } \\
\text { recognition } \\
\end{array}$ \\
\hline $\begin{array}{c}\text { Transgenic } \\
\text { animal studies }\end{array}$ & $\mathrm{N}=$ & Animal & $\begin{array}{l}\text { Trauma } \\
\text { Model }\end{array}$ & $\begin{array}{c}\text { BDNF } \\
\text { Analysis }\end{array}$ & Site of Analysis & $\begin{array}{c}\text { Date of } \\
\text { Analysis }\end{array}$ & BDNF Expression & Functional Tests \\
\hline $\begin{array}{l}\text { (Giarratana } \\
\text { et al. 2019) [110] }\end{array}$ & 4-6/group & Mouse & $\begin{array}{l}\text { Lateral fluid } \\
\text { percussion } \\
\text { (repeated } \\
\text { mild TBI) }\end{array}$ & Western blot & $\begin{array}{l}\text { Cortex and } \\
\text { hippocampus }\end{array}$ & 1 and $21 \mathrm{DPI}$ & $\begin{array}{l}\text { Decreased total BDNF in } \\
\text { Val66Met in ipsilateral } \\
\text { cortex at } 21 \text { DPI, } \\
\text { increased } \\
\text { pro/mature-BDNF in } \\
\text { hippocampus at } 1 \text { DPI } \\
\text { compared to Val66Val. }\end{array}$ & $\begin{array}{l}\text { Rotarod, balance } \\
\text { beam, and } \\
\text { Morris water } \\
\text { maze }\end{array}$ \\
\hline $\begin{array}{l}\text { Gao et al. (2009) } \\
\text { [111] }\end{array}$ & 5-10/group & Mouse & $\mathrm{CCI}$ & $\begin{array}{l}\text { Western blot and im- } \\
\text { munohistochemistry }\end{array}$ & Hippocampus & 1 and 21 DPI & $\begin{array}{l}\text { TBI significantly } \\
\text { increased the level of } \\
\text { BDNF protein in the } \\
\text { dentate gyrus, but less in } \\
\text { conditional KO mice }\end{array}$ & Not performed \\
\hline $\begin{array}{l}\text { Cheng et al. } \\
\text { (2017) [112] }\end{array}$ & 4/group & Mouse & $\mathrm{CCI}$ & Western blot & Cortex & 1 and 21 DPI & $\begin{array}{c}\text { TBI increased BDNF } \\
\text { protein expression in both } \\
\text { contra- and ipsilaterally } \\
\text { in WT at } 21 \text { days after } \\
\text { trauma. In TSP-1 KO } \\
\text { BDNF increased only } \\
\text { ipsilaterally. }\end{array}$ & $\begin{array}{l}\text { Neurological } \\
\text { severity score, } \\
\text { Morris water } \\
\text { maze, wire grip } \\
\text { and corner test }\end{array}$ \\
\hline
\end{tabular}


Table A3. Overview of the reviewed studies examining BDNF polymorphism in humans and a short summary of their reported results.

\begin{tabular}{|c|c|c|c|}
\hline $\begin{array}{l}\text { BDNF Polymorphism and } \\
\text { TBI in Humans }\end{array}$ & Genes and Polymorphism & Findings & Limitations \\
\hline (Davidson et al. 2015) [150] & $\begin{array}{l}\text { Several genes including BDNF } \\
\text { rs6265. }\end{array}$ & $\begin{array}{c}\text { Met-carriers slower reaction } \\
\text { time both healthy subjects and } \\
\text { post TBI. No association with } \\
\text { PTSD. }\end{array}$ & $\begin{array}{l}\text { Few and small studies. } \\
\text { Met-carriers one group } \\
\text { including both heterozygote } \\
\text { and homozygote. }\end{array}$ \\
\hline (Zeiler et al. 2019) [3] & $\begin{array}{l}\text { Several genes, including } \\
\text { rs6265 and other } \\
\text { polymorphisms of BDNF }\end{array}$ & $\begin{array}{l}\text { Varying results for BDNF } \\
\text { rs6265. Some studies show } \\
\text { better cognitive function for } \\
\text { met-carriers, others better } \\
\text { results for val-homozygote. } \\
\text { Higher mortality first year for } \\
\text { met-carriers. }\end{array}$ & $\begin{array}{l}\text { Small studies with } \\
\text { overlapping cohorts. Bias } \\
\text { towards positive results. Risk } \\
\text { for confounding factors. }\end{array}$ \\
\hline (Finan et al. 2018) [151] & BDNF rs6265 & $\begin{array}{l}\text { The effect of the Met-allele } \\
\text { depends on time point after TBI. } \\
\text { Early evaluation, negative } \\
\text { impact on cognition while } \\
\text { protective effect of cognition at } \\
\text { a later timing (years). }\end{array}$ & $\begin{array}{l}\text { Confounding factors: gender, } \\
\text { age, injury, severity, ethnicity, } \\
\text { time point. Interaction with } \\
\text { other genetic polymorphisms. }\end{array}$ \\
\hline
\end{tabular}

\section{References}

1. Ghajar, J. Traumatic brain injury. Lancet 2000, 356, 923-929. [CrossRef]

2. Huang, E.J.; Reichardt, L.F. Neurotrophins: Roles in neuronal development and function. Annu. Rev. Neurosci. 2001, $24,677-736$. [CrossRef] [PubMed]

3. Zeiler, F.A.; McFadyen, C.; Newcombe, V.F.J.; Synnot, A.; Donoghue, E.L.; Ripatti, S.; Steyerberg, E.W.; Gruen, R.L.; McAllister, T.W.; Rosand, J.; et al. Genetic Influences on Patient-Oriented Outcomes in Traumatic Brain Injury: A Living Systematic Review of Non-Apolipoprotein E Single-Nucleotide Polymorphisms. J. Neurotrauma 2019. [CrossRef] [PubMed]

4. Leibrock, J.; Lottspeich, F.; Hohn, A.; Hofer, M.; Hengerer, B.; Masiakowski, P.; Thoenen, H.; Barde, Y.A. Molecular cloning and expression of brain-derived neurotrophic factor. Nature 1989, 341, 149-152. [CrossRef]

5. Lipsky, R.H.; Marini, A.M. Brain-derived neurotrophic factor in neuronal survival and behavior-related plasticity. Ann. N. Y. Acad. Sci. 2007, 1122, 130-143. [CrossRef]

6. Poo, M.M. Neurotrophins as synaptic modulators. Nat. Rev. Neurosci. 2001, 2, 24-32. [CrossRef]

7. Klein, R.; Jing, S.Q.; Nanduri, V.; O'Rourke, E.; Barbacid, M. The trk proto-oncogene encodes a receptor for nerve growth factor. Cell 1991, 65, 189-197. [CrossRef]

8. Frisen, J.; Verge, V.M.; Fried, K.; Risling, M.; Persson, H.; Trotter, J.; Hokfelt, T.; Lindholm, D. Characterization of glial trkB receptors: Differential response to injury in the central and peripheral nervous systems. Proc. Natl. Acad. Sci. USA 1993, 90, 4971-4975. [CrossRef]

9. Rostami, E.; Krueger, F.; Plantman, S.; Davidsson, J.; Agoston, D.; Grafman, J.; Risling, M. Alteration in BDNF and its receptors, full-length and truncated TrkB and p75(NTR) following penetrating traumatic brain injury. Brain Res. 2014, 1542, 195-205. [CrossRef]

10. Dechant, G.; Barde, Y.A. The neurotrophin receptor p75(NTR): Novel functions and implications for diseases of the nervous system. Nat. Neurosci. 2002, 5, 1131-1136. [CrossRef]

11. Egan, M.F.; Kojima, M.; Callicott, J.H.; Goldberg, T.E.; Kolachana, B.S.; Bertolino, A.; Zaitsev, E.; Gold, B.; Goldman, D.; Dean, M.; et al. The BDNF val66met Polymorphism Affects Activity-Dependent Secretion of BDNF and Human Memory and Hippocampal Function and its val/met polymorphism in human memory and hippocampal function and suggest val/met exerts these effects by impacting intracellular trafficking and activity-dependent secretion of BDNF. Cell 2003, 112, 257-269.

12. Notaras, M.; Hill, R.; van den Buuse, M. The BDNF gene Val66Met polymorphism as a modifier of psychiatric disorder susceptibility: Progress and controversy. Mol. Psychiatry 2015, 20, 916-930. [CrossRef] [PubMed]

13. Ramasamy, D.P.; Ramanathan, M.; Cox, J.L.; Antulov, R.; Weinstock-Guttman, B.; Bergsland, N.; Benedict, R.H.; Dwyer, M.G.; Minagar, A.; Zivadinov, R. Effect of Met66 allele of the BDNF rs6265 SNP on regional gray matter volumes in patients with multiple sclerosis: A voxel-based morphometry study. Pathophysiology 2011, 18, 53-60. [CrossRef] [PubMed]

14. Voineskos, A.N.; Lerch, J.P.; Felsky, D.; Shaikh, S.; Rajji, T.K.; Miranda, D.; Lobaugh, N.J.; Mulsant, B.H.; Pollock, B.G.; Kennedy, J.L. The Brain-Derived Neurotrophic Factor Val66Met Polymorphism and Prediction of Neural Risk for Alzheimer Disease. Arch. Gen. Psychiatry 2011, 68, 198-206. [CrossRef] [PubMed]

15. Harris, S.E.; Fox, H.; Wright, A.F.; Hayward, C.; Starr, J.M.; Whalley, L.J.; Deary, I.J. The brain-derived neurotrophic factor Val66Met polymorphism is associated with age-related change in reasoning skills. Mol. Psychiatry 2006, 11, 505-513. [CrossRef] 
16. Krueger, F.; Pardini, M.; Huey, E.D.; Raymont, V.; Solomon, J.; Lipsky, R.H.; Hodgkinson, C.A.; Goldman, D.; Grafman, J. The role of the met66 brain-derived neurotrophic factor allele in the recovery of executive functioning after combat-related traumatic brain injury. J. Neurosci. 2011, 31, 598-606. [CrossRef] [PubMed]

17. McAllister, T.W.; Tyler, A.L.; Flashman, L.A.; Rhodes, C.H.; McDonald, B.C.; Saykin, A.J.; Tosteson, T.D.; Tsongalis, G.J.; Moore, J.H. Polymorphisms in the brain-derived neurotrophic factor gene influence memory and processing speed one month after brain injury. J. Neurotrauma 2012, 29, 1111-1118. [CrossRef]

18. Failla, M.D.; Kumar, R.G.; Peitzman, A.B.; Conley, Y.P.; Ferrell, R.E.; Wagner, A.K. Variation in the BDNF gene interacts with age to predict mortality in a prospective, longitudinal cohort with severe TBI. Neurorehabilit. Neural Repair 2015, 29, 234-246. [CrossRef]

19. Munoz, M.J.; Kumar, R.G.; Oh, B.M.; Conley, Y.P.; Wang, Z.; Failla, M.D.; Wagner, A.K. Cerebrospinal fluid cortisol mediates brain-derived neurotrophic factor relationships to mortality after severe TBI: A prospective cohort study. Front. Mol. Neurosci. 2017, 10, 44. [CrossRef]

20. Rostami, E.; Krueger, F.; Zoubak, S.; Monte, O.D.; Raymont, V.; Pardini, M.; Hodgkinson, C.A.; Goldman, D.; Risling, M.; Grafman, J. Bdnf polymorphism predicts general intelligence after penetrating traumatic brain injury. PLoS ONE 2011, 6, e27389. [CrossRef]

21. Hayes, J.P.; Reagan, A.; Logue, M.W.; Hayes, S.M.; Sadeh, N.; Miller, D.R.; Verfaellie, M.; Wolf, E.J.; McGlinchey, R.E.; Milberg, W.P.; et al. BDNF genotype is associated with hippocampal volume in mild traumatic brain injury. Genes Brain Behav. 2018, 17, 107-117. [CrossRef] [PubMed]

22. Shimizu, E.; Hashimoto, K.; Iyo, M. Ethnic difference of the BDNF 196G/A (val66met) polymorphism frequencies: The possibility to explain ethnic mental traits. Am. J. Med. Genet. B Neuropsychiatr. Genet. 2004, 126B, 122-123. [CrossRef] [PubMed]

23. Petryshen, T.L.; Sabeti, P.C.; Aldinger, K.A.; Fry, B.; Fan, J.B.; Schaffner, S.F.; Waggoner, S.G.; Tahl, A.R.; Sklar, P. Population genetic study of the brain-derived neurotrophic factor (BDNF) gene. Mol. Psychiatry 2010, 15, 810-815. [CrossRef] [PubMed]

24. Dretsch, M.N.; Williams, K.; Emmerich, T.; Crynen, G.; Ait-Ghezala, G.; Chaytow, H.; Mathura, V.; Crawford, F.C.; Iverson, G.L. Brain-derived neurotropic factor polymorphisms, traumatic stress, mild traumatic brain injury, and combat exposure contribute to postdeployment traumatic stress. Brain Behav. 2016, 6, 1-12. [CrossRef] [PubMed]

25. Larson-Dupuis, C.; Chamard, É.; Falardeau, V.; Frasnelli, J.; Beaulieu, C.; Poirier, J.; Carrier, J.; Lassonde, M.; Théoret, H.; Bacon, B.A.; et al. Impact of BDNF Val66Met polymorphism on olfactory functions of female concussed athletes. Brain Inj. 2015, 29, 963-970. [CrossRef]

26. Hariri, A.R.; Goldberg, T.E.; Mattay, V.S.; Kolachana, B.S.; Callicott, J.H.; Egan, M.F.; Weinberger, D.R. Brain-Derived Neurotrophic Factor val 66 met Polymorphism Affects Human Memory-Related Hippocampal Activity and Predicts Memory Performance. J. Neurosci. 2003, 23, 6690-6694. [CrossRef]

27. Narayanan, V.; Veeramuthu, V.; Ahmad-Annuar, A.; Ramli, N.; Waran, V.; Chinna, K.; Bondi, M.W.; Delano-Wood, L.; Ganesan, D. Missense mutation of Brain Derived Neurotrophic Factor (BDNF) alters neurocognitive performance in patients with mild traumatic brain injury: A longitudinal study. PLOS ONE 2016, 11, e0158838.

28. Merritt, V.C.; Clark, A.L.; Evangelista, N.D.; Sorg, S.F.; Schiehser, D.M.; Delano-Wood, L. Dissociation of BDNF Val66Met polymorphism on neurocognitive functioning in military veterans with and without a history of remote mild traumatic brain injury. Clin. Neuropsychol. 2020, 34, 1226-1247. [CrossRef]

29. Mendez, M.F. What is the Relationship of Traumatic Brain Injury to Dementia? J. Alzheimers Dis. 2017, 57, 667-681. [CrossRef]

30. Nordström, A.; Nordström, P. Traumatic brain injury and the risk of dementia diagnosis: A nationwide cohort study. PLoS Med. 2018, 15, e1002496. [CrossRef]

31. Barnes, D.E.; Byers, A.L.; Gardner, R.C.; Seal, K.H.; Boscardin, W.J.; Yaffe, K. Association of mild traumatic brain injury with and without loss of consciousness with dementia in US military veterans. JAMA Neurol. 2018, 75, 1055-1061. [CrossRef]

32. Hunter, L.E.; Freudenberg-Hua, Y.; Davies, P.; Kim, M.; Fleysher, R.; Stewart, W.F.; Lipton, R.B.; Lipton, M.L. BDNF Val66Met Positive Players Demonstrate Diffusion Tensor Imaging Consistent with Impaired Myelination Associated With High Levels of Soccer Heading: Indication of a Potential Gene-Environment Interaction Mechanism. Front. Neurol. 2019, 10, 10. [CrossRef]

33. Failla, M.D.; Conley, Y.P.; Wagner, A.K. Brain-Derived Neurotrophic Factor (BDNF) in Traumatic Brain Injury-Related Mortality: Interrelationships between Genetics and Acute Systemic and Central Nervous System BDNF Profiles. Neurorehabilit. Neural Repair 2016, 30, 83-93. [CrossRef]

34. Van Praag, D.L.G.; Cnossen, M.C.; Polinder, S.; Wilson, L.; Maas, A.I.R. Post-Traumatic Stress Disorder after Civilian Traumatic Brain Injury: A Systematic Review and Meta-Analysis of Prevalence Rates. J. Neurotrauma 2019, 36, 3220-3232. [CrossRef]

35. Bombardier, C.H.; Fann, J.R.; Temkin, N.R.; Esselman, P.C.; Barber, J.; Dikmen, S.S. Rates of major depressive disorder and clinical outcomes following traumatic brain injury. JAMA 2010, 303, 1938-1945. [CrossRef]

36. Wang, Y.J.; Chen, K.Y.; Kuo, L.N.; Wang, W.C.; Hsu, Y.W.; Wong, H.S.C.; Lin, C.M.; Liao, K.H.; Zhang, Y.F.; Chiang, Y.H.; et al. The association between BDNF Val66Met polymorphism and emotional symptoms after mild traumatic brain injury. BMC Med. Genet. 2018, 19, 13. [CrossRef]

37. Clasen, P.C.; Wells, T.T.; Knopik, V.S.; Mcgeary, J.E.; Beevers, C.G. 5-HTTLPR and BDNF Val66Met polymorphisms moderate effects of stress on rumination. Genes Brain Behav. 2011, 10, 740-746. [CrossRef] [PubMed]

38. Lanctt, K.L.; Rapoport, M.J.; Chan, F.; Rajaram, R.D.; Strauss, J.; Sicard, T.; McCullagh, S.; Feinstein, A.; Kiss, A.; Kennedy, J.L.; et al. Genetic predictors of response to treatment with citalopram in depression secondary to traumatic brain injury. Brain Inj. 2010, 24, 959-969. [CrossRef] [PubMed] 
39. Bagnato, S.; Minafra, L.; Bravatà, V.; Boccagni, C.; Sant'Angelo, A.; Castiglione, A.; Andriolo, M.; Lucca, L.F.; De Tanti, A.; Pistarini, C.; et al. Brain-derived neurotrophic factor (Val66Met) polymorphism does not influence recovery from a post-traumatic vegetative state: A blinded retrospective multi-centric study. J. Neurotrauma 2012, 29, 2050-2059. [CrossRef] [PubMed]

40. Barbey, A.K.; Colom, R.; Paul, E.; Forbes, C.; Krueger, F.; Goldman, D.; Grafman, J. Preservation of general intelligence following traumatic brain injury: Contributions of the Met66 brain-derived neurotrophic factor. PLoS ONE 2014, 9, e88733. [CrossRef] [PubMed]

41. Simon, D.; Nascimento, R.I.M.D.; Filho, E.M.R.; Bencke, J.; Regner, A. Plasma brain-derived neurotrophic factor levels after severe traumatic brain injury. Brain Inj. 2016, 30, 23-28. [CrossRef] [PubMed]

42. Chiaretti, A.; Antonelli, A.; Riccardi, R.; Genovese, O.; Pezzotti, P.; Di Rocco, C.; Tortorolo, L.; Piedimonte, G. Nerve growth factor expression correlates with severity and outcome of traumatic brain injury in children. Eur. J. Paediatr. Neurol. 2008, 12, 195-204. [CrossRef] [PubMed]

43. Colak, T.; Cine, N.; Bamac, B.; Kurtas, O.; Ozbek, A.; Bicer, U.; Sunnetci, D.; Savli, H. Microarray-based gene expression analysis of an animal model for closed head injury. Injury 2012, 43, 1264-1270. [CrossRef]

44. Wang, Y.; Hameed, M.Q.; Rakhade, S.N.; Iglesias, A.H.; Muller, P.A.; Mou, D.L.; Rotenberg, A. Hippocampal immediate early gene transcription in the rat fluid percussion traumatic brain injury model. Neuroreport 2014, 25, 954-959. [CrossRef] [PubMed]

45. Boone, D.R.; Sell, S.L.; Micci, M.A.; Crookshanks, J.M.; Parsley, M.; Uchida, T.; Prough, D.S.; DeWitt, D.S.; Hellmich, H.L. Traumatic brain injury-induced dysregulation of the circadian clock. PLoS ONE 2012, 7, e46204. [CrossRef] [PubMed]

46. Matzilevich, D.A.; Rall, J.M.; Moore, A.N.; Grill, R.J.; Dash, P.K. High-density microarray analysis of hippocampal gene expression following experimental brain injury. J. Neurosci. Res. 2002, 67, 646-663. [CrossRef]

47. Yang, K.; Perez-Polo, J.R.; Mu, X.S.; Yan, H.Q.; Xue, J.J.; Iwamoto, Y.; Liu, S.J.; Dixon, C.E.; Hayes, R.L. Increased expression of brain-derived neurotrophic factor but not neurotrophin-3 mRNA in rat brain after cortical impact injury. J. Neurosci. Res. 1996, 44, 157-164. [CrossRef]

48. Griesbach, G.S.; Sutton, R.L.; Hovda, D.A.; Ying, Z.; Gomez-Pinilla, F. Controlled contusion injury alters molecular systems associated with cognitive performance. J. Neurosci. Res. 2009, 87, 795-805. [CrossRef]

49. Khan, M.; Sakakima, H.; Dhammu, T.S.; Shunmugavel, A.; Im, Y.B.; Gilg, A.G.; Singh, A.K.; Singh, I. S-nitrosoglutathione reduces oxidative injury and promotes mechanisms of neurorepair following traumatic brain injury in rats. J. Neuroinflamm. 2011, 8, 78 . [CrossRef]

50. Dobrachinski, F.; Gerbatin, R.R.; Sartori, G.; Golombieski, R.M.; Antoniazzi, A.; Nogueira, C.W.; Royes, L.F.; Fighera, M.R.; Porciuncula, L.O.; Cunha, R.A.; et al. Guanosine Attenuates Behavioral Deficits After Traumatic Brain Injury by Modulation of Adenosinergic Receptors. Mol. Neurobiol. 2019, 56, 3145-3158. [CrossRef]

51. Krishna, G.; Ying, Z.; Gomez-Pinilla, F. Blueberry Supplementation Mitigates Altered Brain Plasticity and Behavior after Traumatic Brain Injury in Rats. Mol. Nutr. Food Res. 2019, 63, e1801055. [CrossRef] [PubMed]

52. Malik, S.Z.; Motamedi, S.; Royo, N.C.; LeBold, D.; Watson, D.J. Identification of potentially neuroprotective genes upregulated by neurotrophin treatment of CA3 neurons in the injured brain. J. Neurotrauma 2011, 28, 415-430. [CrossRef] [PubMed]

53. Wu, A.; Ying, Z.; Gomez-Pinilla, F. Dietary curcumin counteracts the outcome of traumatic brain injury on oxidative stress, synaptic plasticity, and cognition. Exp. Neurol. 2006, 197, 309-317. [CrossRef] [PubMed]

54. Tyagi, E.; Agrawal, R.; Ying, Z.; Gomez-Pinilla, F. TBI and sex: Crucial role of progesterone protecting the brain in an omega-3 deficient condition. Exp. Neurol. 2014, 253, 41-51. [CrossRef]

55. Wu, A.; Ying, Z.; Gomez-Pinilla, F. The salutary effects of DHA dietary supplementation on cognition, neuroplasticity, and membrane homeostasis after brain trauma. J. Neurotrauma 2011, 28, 2113-2122. [CrossRef]

56. Hou, Z.; Luo, W.; Sun, X.; Hao, S.; Zhang, Y.; Xu, F.; Wang, Z.; Liu, B. Hydrogen-rich saline protects against oxidative damage and cognitive deficits after mild traumatic brain injury. Brain Res. Bull. 2012, 88, 560-565. [CrossRef]

57. Alder, J.; Fujioka, W.; Giarratana, A.; Wissocki, J.; Thakkar, K.; Vuong, P.; Patel, B.; Chakraborty, T.; Elsabeh, R.; Parikh, A.; et al. Genetic and pharmacological intervention of the p75NTR pathway alters morphological and behavioural recovery following traumatic brain injury in mice. Brain Inj. 2016, 30, 48-65. [CrossRef]

58. Griesbach, G.S.; Hovda, D.A.; Molteni, R.; Wu, A.; Gomez-Pinilla, F. Voluntary exercise following traumatic brain injury: Brain-derived neurotrophic factor upregulation and recovery of function. Neuroscience 2004, 125, 129-139. [CrossRef]

59. Griesbach, G.S.; Gomez-Pinilla, F.; Hovda, D.A. Time window for voluntary exercise-induced increases in hippocampal neuroplasticity molecules after traumatic brain injury is severity dependent. J. Neurotrauma 2007, 24, 1161-1171. [CrossRef]

60. Aiguo, W.; Zhe, Y.; Gomez-Pinilla, F. Vitamin E protects against oxidative damage and learning disability after mild traumatic brain injury in rats. Neurorehabil. Neural Repair 2010, 24, 290-298. [CrossRef]

61. Wu, A.; Ying, Z.; Schubert, D.; Gomez-Pinilla, F. Brain and spinal cord interaction: A dietary curcumin derivative counteracts locomotor and cognitive deficits after brain trauma. Neurorehabil. Neural Repair 2011, 25, 332-342. [CrossRef] [PubMed]

62. Chytrova, G.; Ying, Z.; Gomez-Pinilla, F. Exercise normalizes levels of MAG and Nogo-A growth inhibitors after brain trauma. Eur. J. Neurosci. 2008, 27, 1-11. [CrossRef]

63. Griesbach, G.S.; Tio, D.L.; Vincelli, J.; McArthur, D.L.; Taylor, A.N. Differential effects of voluntary and forced exercise on stress responses after traumatic brain injury. J. Neurotrauma 2012, 29, 1426-1433. [CrossRef] [PubMed]

64. Wu, A.; Ying, Z.; Gomez-Pinilla, F. Exercise facilitates the action of dietary DHA on functional recovery after brain trauma. Neuroscience 2013, 248, 655-663. [CrossRef] 
65. Mao, X.; Hao, S.; Zhu, Z.; Zhang, H.; Wu, W.; Xu, F.; Liu, B. Procyanidins protects against oxidative damage and cognitive deficits after traumatic brain injury. Brain Inj. 2015, 29, 86-92. [CrossRef]

66. Da Silva Fiorin, F.; de Oliveira Ferreira, A.P.; Ribeiro, L.R.; Silva, L.F.; de Castro, M.R.; da Silva, L.R.; da Silveira, M.E., Jr.; Zemolin, A.P.; Dobrachinski, F.; Marchesan de Oliveira, S.; et al. The Impact of Previous Physical Training on Redox Signaling after Traumatic Brain Injury in Rats: A Behavioral and Neurochemical Approach. J. Neurotrauma 2016, 33, 1317-1330. [CrossRef] [PubMed]

67. Griesbach, G.S.; Hovda, D.A.; Gomez-Pinilla, F. Exercise-induced improvement in cognitive performance after traumatic brain injury in rats is dependent on BDNF activation. Brain Res. 2009, 1288, 105-115. [CrossRef] [PubMed]

68. Shen, X.; Li, A.; Zhang, Y.; Dong, X.; Shan, T.; Wu, Y.; Jia, J.; Hu, Y. The effect of different intensities of treadmill exercise on cognitive function deficit following a severe controlled cortical impact in rats. Int. J. Mol. Sci. 2013, 14, 21598-21612. [CrossRef]

69. Chou, W.; Liu, Y.F.; Lin, C.H.; Lin, M.T.; Chen, C.C.; Liu, W.P.; Chang, C.P.; Chio, C.C. Exercise Rehabilitation Attenuates Cognitive Deficits in Rats with Traumatic Brain Injury by Stimulating the Cerebral HSP20/BDNF/TrkB Signalling Axis. Mol. Neurobiol. 2018, 55, 8602-8611. [CrossRef]

70. Kobori, N.; Clifton, G.L.; Dash, P. Altered expression of novel genes in the cerebral cortex following experimental brain injury. Brain Res. Mol. Brain Res. 2002, 104, 148-158. [CrossRef]

71. Zhao, Z.; Sabirzhanov, B.; Wu, J.; Faden, A.I.; Stoica, B.A. Voluntary Exercise Preconditioning Activates Multiple Antiapoptotic Mechanisms and Improves Neurological Recovery after Experimental Traumatic Brain Injury. J. Neurotrauma 2015, 32, 1347-1360. [CrossRef]

72. Cheng, T.; Yang, B.; Li, D.; Ma, S.; Tian, Y.; Qu, R.; Zhang, W.; Zhang, Y.; Hu, K.; Guan, F.; et al. Wharton's Jelly Transplantation Improves Neurologic Function in a Rat Model of Traumatic Brain Injury. Cell. Mol. Neurobiol. 2015, 35, 641-649. [CrossRef] [PubMed]

73. Crupi, R.; Paterniti, I.; Campolo, M.; Di Paola, R.; Cuzzocrea, S.; Esposito, E. Exogenous T3 administration provides neuroprotection in a murine model of traumatic brain injury. Pharmacol. Res. 2013, 70, 80-89. [CrossRef] [PubMed]

74. Wu, H.; Shao, A.; Zhao, M.; Chen, S.; Yu, J.; Zhou, J.; Liang, F.; Shi, L.; Dixon, B.J.; Wang, Z.; et al. Melatonin attenuates neuronal apoptosis through up-regulation of $\mathrm{K}(+)-\mathrm{Cl}(-)$ cotransporter $\mathrm{KCC} 2$ expression following traumatic brain injury in rats. J. Pineal Res. 2016, 61, 241-250. [CrossRef]

75. Gugliandolo, E.; D’Amico, R.; Cordaro, M.; Fusco, R.; Siracusa, R.; Crupi, R.; Impellizzeri, D.; Cuzzocrea, S.; Di Paola, R. Neuroprotective Effect of Artesunate in Experimental Model of Traumatic Brain Injury. Front. Neurol. 2018, 9, 590. [CrossRef] [PubMed]

76. Su, W.S.; Wu, C.H.; Chen, S.F.; Yang, F.Y. Transcranial ultrasound stimulation promotes brain-derived neurotrophic factor and reduces apoptosis in a mouse model of traumatic brain injury. Brain Stimul. 2017, 10, 1032-1041. [CrossRef]

77. Ji, X.; Peng, D.; Zhang, Y.; Zhang, J.; Wang, Y.; Gao, Y.; Lu, N.; Tang, P. Astaxanthin improves cognitive performance in mice following mild traumatic brain injury. Brain Res. 2017, 1659, 88-95. [CrossRef]

78. Griesbach, G.S.; Gomez-Pinilla, F.; Hovda, D.A. The upregulation of plasticity-related proteins following TBI is disrupted with acute voluntary exercise. Brain Res. 2004, 1016, 154-162. [CrossRef]

79. Xiong, L.L.; Hu, Y.; Zhang, P.; Zhang, Z.; Li, L.H.; Gao, G.D.; Zhou, X.F.; Wang, T.H. Neural Stem Cell Transplantation Promotes Functional Recovery from Traumatic Brain Injury via Brain Derived Neurotrophic Factor-Mediated Neuroplasticity. Mol. Neurobiol. 2018, 55, 2696-2711. [CrossRef]

80. Meng, Y.; Chopp, M.; Zhang, Y.; Liu, Z.; An, A.; Mahmood, A.; Xiong, Y. Subacute intranasal administration of tissue plasminogen activator promotes neuroplasticity and improves functional recovery following traumatic brain injury in rats. PLoS ONE 2014, 9, e106238. [CrossRef]

81. Feng, Y.; Ju, Y.; Cui, J.; Wang, L. Bone marrow stromal cells promote neuromotor functional recovery, via upregulation of neurotrophic factors and synapse proteins following traumatic brain injury in rats. Mol. Med. Rep. 2017, 16, 654-660. [CrossRef]

82. Zhao, Y.; Lee, J.H.; Chen, D.; Gu, X.; Caslin, A.; Li, J.; Yu, S.P.; Wei, L. DL-3-n-butylphthalide induced neuroprotection, regenerative repair, functional recovery and psychological benefits following traumatic brain injury in mice. Neurochem. Int. 2017, 111, 82-92. [CrossRef] [PubMed]

83. Sen, T.; Gupta, R.; Kaiser, H.; Sen, N. Activation of PERK Elicits Memory Impairment through Inactivation of CREB and Downregulation of PSD95 after Traumatic Brain Injury. J. Neurosci. 2017, 37, 5900-5911. [CrossRef] [PubMed]

84. Chang, P.; Williams, A.M.; Bhatti, U.F.; Biesterveld, B.E.; Liu, B.; Nikolian, V.C.; Dennahy, I.S.; Lee, J.; Li, Y.; Alam, H.B. Valproic Acid and Neural Apoptosis, Inflammation, and Degeneration 30 Days after Traumatic Brain Injury, Hemorrhagic Shock, and Polytrauma in a Swine Model. J. Am. Coll. Surg. 2019, 228, 265-275. [CrossRef]

85. Ma, D.; Wang, N.; Fan, X.; Zhang, L.; Luo, Y.; Huang, R.; Zhang, L.; Li, Y.; Zhao, G.; Li, L. Protective Effects of Cornel Iridoid Glycoside in Rats After Traumatic Brain Injury. Neurochem. Res. 2018, 43, 959-971. [CrossRef]

86. Yin, R.; Zhao, S.; Qiu, C. Brain-derived neurotrophic factor fused with a collagen-binding domain inhibits neuroinflammation and promotes neurological recovery of traumatic brain injury mice via TrkB signalling. J. Pharm. Pharmacol. 2020, 72, 539-550. [CrossRef] 
87. Della-Pace, I.D.; Souza, T.L.; Grauncke, A.C.B.; Rambo, L.M.; Ribeiro, L.R.; Cipolatto, R.P.; Severo, L.; Papalia, W.L.; Santos, A.R.S.; Facundo, V.A.; et al. Modulation of $\mathrm{Na}(+) / \mathrm{K}(+)$ - ATPase activity by triterpene 3beta, 6beta, 16beta-trihidroxilup-20 (29)-ene (TTHL) limits the long-term secondary degeneration after traumatic brain injury in mice. Eur. J. Pharmacol. 2019, 854, 387-397. [CrossRef] [PubMed]

88. Cekic, M.; Johnson, S.J.; Bhatt, V.H.; Stein, D.G. Progesterone treatment alters neurotrophin/proneurotrophin balance and receptor expression in rats with traumatic brain injury. Restor. Neurol. Neurosci. 2012, 30, 115-126. [CrossRef] [PubMed]

89. Nagamoto-Combs, K.; McNeal, D.W.; Morecraft, R.J.; Combs, C.K. Prolonged microgliosis in the rhesus monkey central nervous system after traumatic brain injury. J. Neurotrauma 2007, 24, 1719-1742. [CrossRef]

90. Corne, R.; Leconte, C.; Ouradou, M.; Fassina, V.; Zhu, Y.; Deou, E.; Besson, V.; Plotkine, M.; Marchand-Leroux, C.; Mongeau, R. Spontaneous resurgence of conditioned fear weeks after successful extinction in brain injured mice. Prog. Neuropsychopharmacol. Biol. Psychiatry 2019, 88, 276-286. [CrossRef]

91. Griesbach, G.S.; Tio, D.L.; Nair, S.; Hovda, D.A. Recovery of stress response coincides with responsiveness to voluntary exercise after traumatic brain injury. J. Neurotrauma 2014, 31, 674-682. [CrossRef] [PubMed]

92. Hicks, R.R.; Boggs, A.; Leider, D.; Kraemer, P.; Brown, R.; Scheff, S.W.; Seroogy, K.B. Effects of Exercise Following Lateral Fluid Percussion Brain Injury in Rats. Restor. Neurol. Neurosci. 1998, 12, 41-47. [PubMed]

93. Shin, M.S.; Park, H.K.; Kim, T.W.; Ji, E.S.; Lee, J.M.; Choi, H.S.; Kim, M.Y.; Kim, Y.P. Neuroprotective Effects of Bone Marrow Stromal Cell Transplantation in Combination with Treadmill Exercise Following Traumatic Brain Injury. Int. Neurourol. J. 2016, 20 (Suppl. S1), S49-S56. [CrossRef] [PubMed]

94. Rich, N.J.; Van Landingham, J.W.; Figueiroa, S.; Seth, R.; Corniola, R.S.; Levenson, C.W. Chronic caloric restriction reduces tissue damage and improves spatial memory in a rat model of traumatic brain injury. J. Neurosci. Res. 2010, 88, 2933-2939. [CrossRef] [PubMed]

95. Chandrasekar, A.; Aksan, B.; Heuvel, F.O.; Forstner, P.; Sinske, D.; Rehman, R.; Palmer, A.; Ludolph, A.; Huber-Lang, M.; Bockers, T.; et al. Neuroprotective effect of acute ethanol intoxication in TBI is associated to the hierarchical modulation of early transcriptional responses. Exp. Neurol. 2018, 302, 34-45. [CrossRef]

96. Ignowski, E.; Winter, A.N.; Duval, N.; Fleming, H.; Wallace, T.; Manning, E.; Koza, L.; Huber, K.; Serkova, N.J.; Linseman, D.A. The cysteine-rich whey protein supplement, Immunocal(R), preserves brain glutathione and improves cognitive, motor, and histopathological indices of traumatic brain injury in a mouse model of controlled cortical impact. Free Radic. Biol. Med. 2018, 124, 328-341. [CrossRef]

97. Ren, Y.Z.; Zhang, B.Z.; Zhao, X.J.; Zhang, Z.Y. Resolvin D1 ameliorates cognitive impairment following traumatic brain injury via protecting astrocytic mitochondria. J. Neurochem. 2020, 154, 530-546. [CrossRef] [PubMed]

98. Portbury, S.D.; Hare, D.J.; Finkelstein, D.I.; Adlard, P.A. Trehalose improves traumatic brain injury-induced cognitive impairment. PLoS ONE 2017, 12, e0183683. [CrossRef]

99. Agrawal, R.; Tyagi, E.; Vergnes, L.; Reue, K.; Gomez-Pinilla, F. Coupling energy homeostasis with a mechanism to support plasticity in brain trauma. Biochim. Biophys. Acta 2014, 1842, 535-546. [CrossRef]

100. Mahmood, A.; Lu, D.; Chopp, M. Intravenous administration of marrow stromal cells (MSCs) increases the expression of growth factors in rat brain after traumatic brain injury. J. Neurotrauma 2004, 21, 33-39. [CrossRef]

101. Mahmood, A.; Lu, D.; Qu, C.; Goussev, A.; Chopp, M. Long-term recovery after bone marrow stromal cell treatment of traumatic brain injury in rats. J. Neurosurg. 2006, 104, 272-277. [CrossRef]

102. Deng, Q.J.; Xu, X.F.; Ren, J. Effects of SDF-1/CXCR4 on the Repair of Traumatic Brain Injury in Rats by Mediating Bone Marrow Derived Mesenchymal Stem Cells. Cell. Mol. Neurobiol. 2018, 38, 467-477. [CrossRef] [PubMed]

103. Kim, H.J.; Lee, J.H.; Kim, S.H. Therapeutic effects of human mesenchymal stem cells on traumatic brain injury in rats: Secretion of neurotrophic factors and inhibition of apoptosis. J. Neurotrauma 2010, 27, 131-138. [CrossRef] [PubMed]

104. Qi, L.; Xue, X.; Sun, J.; Wu, Q.; Wang, H.; Guo, Y.; Sun, B. The Promising Effects of Transplanted Umbilical Cord Mesenchymal Stem Cells on the Treatment in Traumatic Brain Injury. J. Craniofac. Surg. 2018, 29, 1689-1692. [CrossRef] [PubMed]

105. Wang, Y.; Peng, D.; Yang, X.; Huang, P.; Ye, H.; Hui, Y.; Wang, X.; Sun, W.; Wu, H.; Zhang, S.; et al. Study on Umbilical Cord-Matrix Stem Cells Transplantation for Treatment of Acute Traumatic Brain Injury in Rats. Turk. Neurosurg. 2019, 29, 750-758. [PubMed]

106. Khalin, I.; Alyautdin, R.; Wong, T.W.; Gnanou, J.; Kocherga, G.; Kreuter, J. Brain-derived neurotrophic factor delivered to the brain using poly (lactide-co-glycolide) nanoparticles improves neurological and cognitive outcome in mice with traumatic brain injury. Drug Deliv. 2016, 23, 3520-3528. [CrossRef]

107. Wu, C.H.; Hung, T.H.; Chen, C.C.; Ke, C.H.; Lee, C.Y.; Wang, P.Y.; Chen, S.F. Post-injury treatment with 7,8-dihydroxyflavone, a TrkB receptor agonist, protects against experimental traumatic brain injury via PI3K/Akt signaling. PLoS ONE 2014, 9, e113397. [CrossRef]

108. Krishna, G.; Agrawal, R.; Zhuang, Y.; Ying, Z.; Paydar, A.; Harris, N.G.; Royes, L.F.F.; Gomez-Pinilla, F. 7,8-Dihydroxyflavone facilitates the action exercise to restore plasticity and functionality: Implications for early brain trauma recovery. Biochim. Biophys. Acta Mol. Basis Dis. 2017, 1863, 1204-1213. [CrossRef]

109. Delbary-Gossart, S.; Lee, S.; Baroni, M.; Lamarche, I.; Arnone, M.; Canolle, B.; Lin, A.; Sacramento, J.; Salegio, E.A.; Castel, M.N.; et al. A novel inhibitor of p75-neurotrophin receptor improves functional outcomes in two models of traumatic brain injury. Brain 2016, 139 Pt 6, 1762-1782. [CrossRef] 
110. Giarratana, A.O.; Teng, S.; Reddi, S.; Zheng, C.; Adler, D.; Thakker-Varia, S.; Alder, J. BDNF Val66Met Genetic Polymorphism Results in Poor Recovery Following Repeated Mild Traumatic Brain Injury in a Mouse Model and Treatment With AAV-BDNF Improves Outcomes. Front. Neurol. 2019, 10, 1175. [CrossRef]

111. Gao, X.; Chen, J. Conditional knockout of brain-derived neurotrophic factor in the hippocampus increases death of adult-born immature neurons following traumatic brain injury. J. Neurotrauma 2009, 26, 1325-1335. [CrossRef] [PubMed]

112. Cheng, C.; Yu, Z.; Zhao, S.; Liao, Z.; Xing, C.; Jiang, Y.; Yang, Y.G.; Whalen, M.J.; Lo, E.H.; Sun, X.; et al. Thrombospondin-1 Gene Deficiency Worsens the Neurological Outcomes of Traumatic Brain Injury in Mice. Int. J. Med. Sci. 2017, 14, 927-936. [CrossRef] [PubMed]

113. Morrison, B., 3rd; Elkin, B.S.; Dolle, J.P.; Yarmush, M.L. In vitro models of traumatic brain injury. Annu. Rev. Biomed. Eng. 2011, 13, 91-126. [CrossRef]

114. Thelin, E.P.; Hall, C.E.; Tyzack, G.E.; Frostell, A.; Giorgi-Coll, S.; Alam, A.; Carpenter, K.L.H.; Mitchell, J.; Tajsic, T.; Hutchinson, P.J.; et al. Delineating Astrocytic Cytokine Responses in a Human Stem Cell Model of Neural Trauma. J. Neurotrauma 2020, 37, 93-105. [CrossRef] [PubMed]

115. Sherman, S.A.; Phillips, J.K.; Costa, J.T.; Cho, F.S.; Oungoulian, S.R.; Finan, J.D. Stretch Injury of Human Induced Pluripotent Stem Cell Derived Neurons in a 96 Well Format. Sci. Rep. 2016, 6, 34097. [CrossRef] [PubMed]

116. Zander, N.E.; Piehler, T.; Hogberg, H.; Pamies, D. Explosive Blast Loading on Human 3D Aggregate Minibrains. Cell. Mol. Neurobiol. 2017, 37, 1331-1334. [CrossRef] [PubMed]

117. Lai, J.D.; Berlind, J.E.; Fricklas, G.; Maria, N.S.; Jacobs, R.; Yu, V.; Ichida, J.K. A model of traumatic brain injury using human iPSC-derived cortical brain organoids. BioRxiv 2020. [CrossRef]

118. Xu, X.; Garcia, J.; Ewalt, R.; Nason, S.; Pozzo-Miller, L. The BDNF val-66-met Polymorphism Affects Neuronal Morphology and Synaptic Transmission in Cultured Hippocampal Neurons from Rett Syndrome Mice. Front. Cell. Neurosci. 2017, 11, 203. [CrossRef]

119. Shen, T.; You, Y.; Joseph, C.; Mirzaei, M.; Klistorner, A.; Graham, S.L.; Gupta, V. BDNF Polymorphism: A Review of Its Diagnostic and Clinical Relevance in Neurodegenerative Disorders. Aging Dis. 2018, 9, 523-536. [CrossRef]

120. Gabrys, R.L.; Dixon, K.; Holahan, M.R.; Anisman, H. Self-Reported Mild Traumatic Brain Injuries in Relation to Rumination and Depressive Symptoms: Moderating Role of Sex Differences and a Brain-Derived Neurotrophic Factor Gene Polymorphism. Clin. J. Sport Med. 2019, 29, 494-499. [CrossRef]

121. Edut, S.; Rubovitch, V.; Rehavi, M.; Schreiber, S.; Pick, C.G. A study on the mechanism by which MDMA protects against dopaminergic dysfunction after minimal traumatic brain injury (mTBI) in mice. J. Mol. Neurosci. 2014, 54, 684-697. [CrossRef] [PubMed]

122. Li, X.; Chen, C.; Yang, X.; Wang, J.; Zhao, M.L.; Sun, H.; Zhang, S.; Tu, Y. Acupuncture Improved Neurological Recovery after Traumatic Brain Injury by Activating BDNF/TrkB Pathway. Evid. Based Complement. Alternat. Med. 2017. [CrossRef] [PubMed]

123. Wang, W.; Shen, M.; Sun, K.; Wang, Y.; Wang, X.; Jin, X.; Xu, J.; Ding, L.; Sun, X. Aminoguanidine reverses cognitive deficits and activation of cAMP/CREB/BDNF pathway in mouse hippocampus after traumatic brain injury (TBI). Brain Inj. 2018, 32, 1858-1865. [CrossRef]

124. Umschweif, G.; Liraz-Zaltsman, S.; Shabashov, D.; Alexandrovich, A.; Trembovler, V.; Horowitz, M.; Shohami, E. Angiotensin receptor type 2 activation induces neuroprotection and neurogenesis after traumatic brain injury. Neurotherapeutics 2014, 11, 665678. [CrossRef] [PubMed]

125. Umschweif, G.; Shabashov, D.; Alexandrovich, A.G.; Trembovler, V.; Horowitz, M.; Shohami, E. Neuroprotection after traumatic brain injury in heat-acclimated mice involves induced neurogenesis and activation of angiotensin receptor type 2 signaling. J. Cereb. Blood Flow Metab. 2014, 34, 1381-1390. [CrossRef]

126. Lee, I.N.; Lin, M.H.; Chung, C.Y.; Lee, M.H.; Weng, H.H.; Yang, J.T. Chronic cigarette smoke exposure enhances brain-derived neurotrophic factor expression in rats with traumatic brain injury. Metab Brain Dis. 2012, 27, 197-204. [CrossRef]

127. Gu, Y.L.; Zhang, L.W.; Ma, N.; Ye, L.L.; Wang de, X.; Gao, X. Cognitive improvement of mice induced by exercise prior to traumatic brain injury is associated with cytochrome c oxidase. Neurosci. Lett. 2014, 570, 86-91. [CrossRef]

128. Yoon, K.J.; Lee, Y.T.; Chae, S.W.; Park, C.R.; Kim, D.Y. Effects of anodal transcranial direct current stimulation (tDCS) on behavioral and spatial memory during the early stage of traumatic brain injury in the rats. J. Neurol. Sci. 2016, 362, 314-320. [CrossRef]

129. Liraz-Zaltsman, S.; Slusher, B.; Atrakchi-Baranes, D.; Rosenblatt, K.; Friedman Levi, Y.; Kesner, E.; Silva, A.J.; Biegon, A.; Shohami, E. Enhancement of Brain d-Serine Mediates Recovery of Cognitive Function after Traumatic Brain Injury. J. Neurotrauma 2018, 35, 1667-1680. [CrossRef]

130. Gatson, J.W.; Liu, M.M.; Abdelfattah, K.; Wigginton, J.G.; Smith, S.; Wolf, S.; Simpkins, J.W.; Minei, J.P. Estrone is neuroprotective in rats after traumatic brain injury. J. Neurotrauma 2012, 29, 2209-2219. [CrossRef]

131. Grundy, P.L.; Patel, N.; Harbuz, M.S.; Lightman, S.L.; Sharples, P.M. Glucocorticoids modulate BDNF mRNA expression in the rat hippocampus after traumatic brain injury. Neuroreport 2000, 11, 3381-3384. [CrossRef] [PubMed]

132. Song, S.; Kong, X.; Acosta, S.; Sava, V.; Borlongan, C.; Sanchez-Ramos, J. Granulocyte colony-stimulating factor promotes behavioral recovery in a mouse model of traumatic brain injury. J. Neurosci. Res. 2016, 94, 409-423. [CrossRef] [PubMed]

133. Algamal, M.; Saltiel, N.; Pearson, A.J.; Ager, B.; Burca, I.; Mouzon, B.; Diamond, D.M.; Mullan, M.; Ojo, J.O.; Crawford, F. Impact of Repetitive Mild Traumatic Brain Injury on Behavioral and Hippocampal Deficits in a Mouse Model of Chronic Stress. J. Neurotrauma 2019, 36, 2590-2607. [CrossRef] [PubMed] 
134. Ko, I.G.; Kim, S.E.; Hwang, L.; Jin, J.J.; Kim, C.J.; Kim, B.K.; Kim, H. Late starting treadmill exercise improves spatial leaning ability through suppressing CREP/BDNF/TrkB signaling pathway following traumatic brain injury in rats. J. Exerc. Rehabil. 2018, 14, 327-334. [CrossRef]

135. Mahmood, A.; Goussev, A.; Kazmi, H.; Qu, C.; Lu, D.; Chopp, M. Long-term benefits after treatment of traumatic brain injury with simvastatin in rats. Neurosurgery 2009, 65, 187-191. [CrossRef]

136. Xuan, W.; Agrawal, T.; Huang, L.; Gupta, G.K.; Hamblin, M.R. Low-level laser therapy for traumatic brain injury in mice increases brain derived neurotrophic factor (BDNF) and synaptogenesis. J. Biophotonics 2015, 8, 502-511. [CrossRef]

137. Shah, S.A.; Prough, D.S.; Garcia, J.M.; DeWitt, D.S.; Hellmich, H.L. Molecular correlates of age-specific responses to traumatic brain injury in mice. Exp. Gerontol. 2006, 41, 1201-1205. [CrossRef]

138. Esenaliev, R.O.; Petrov, I.Y.; Petrov, Y.; Guptarak, J.; Boone, D.R.; Mocciaro, E.; Weisz, H.; Parsley, M.A.; Sell, S.L.; Hellmich, H.; et al. Nano-Pulsed Laser Therapy Is Neuroprotective in a Rat Model of Blast-Induced Neurotrauma. J. Neurotrauma 2018, 35, 1510-1522. [CrossRef] [PubMed]

139. Bhatt, S.; Mahesh, R.; Jindal, A.; Devadoss, T. Neuropharmacological and neurochemical evaluation of N-n-propyl-3ethoxyquinoxaline-2-carboxamide (6n): A novel serotonergic 5-HT3 receptor antagonist for co-morbid antidepressant- and anxiolytic-like potential using traumatic brain injury model in rats. J. Basic Clin. Physiol. Pharmacol. 2017, 28, 93-100. [CrossRef]

140. Sonmez, A.; Sayin, O.; Gurgen, S.G.; Calisir, M. Neuroprotective effects of MK-801 against traumatic brain injury in immature rats. Neurosci. Lett. 2015, 597, 137-142. [CrossRef]

141. Shang, J.L.; Cheng, Q.; Yang, W.F.; Zhang, M.; Cui, Y.; Wang, Y.F. Possible roles of COX-1 in learning and memory impairment induced by traumatic brain injury in mice. Br. J. Med. Biol. Res. 2014, 47, 1050-1056. [CrossRef]

142. Ghadiri, T.; Vakilzadeh, G.; Hajali, V.; Khodagholi, F. Progesterone modulates post-traumatic epileptogenesis through regulation of BDNF-TrkB signaling and cell survival-related pathways in the rat hippocampus. Neurosci. Lett. 2019, 709, 134384. [CrossRef]

143. Oyesiku, N.M.; Evans, C.O.; Houston, S.; Darrell, R.S.; Smith, J.S.; Fulop, Z.L.; Dixon, C.E.; Stein, D.G. Regional changes in the expression of neurotrophic factors and their receptors following acute traumatic brain injury in the adult rat brain. Brain Res. 1999, 833, 161-172. [CrossRef]

144. Golz, C.; Kirchhoff, F.P.; Westerhorstmann, J.; Schmidt, M.; Hirnet, T.; Rune, G.M.; Bender, R.A.; Schafer, M.K.E. Sex hormones modulate pathogenic processes in experimental traumatic brain injury. J. Neurochem. 2019, 150, 173-187. [CrossRef]

145. Cutler, S.M.; Vanlandingham, J.W.; Stein, D.G. Tapered progesterone withdrawal promotes long-term recovery following brain trauma. Exp. Neurol. 2006, 200, 378-385. [CrossRef] [PubMed]

146. Mychasiuk, R.; Hehar, H.; Candy, S.; Ma, I.; Esser, M.J. The direction of the acceleration and rotational forces associated with mild traumatic brain injury in rodents effect behavioural and molecular outcomes. J. Neurosci. Methods 2016, 257, 168-178. [CrossRef]

147. Xing, P.; Ma, K.; Li, L.; Wang, D.; Hu, G.; Long, W. The protection effect and mechanism of hyperbaric oxygen therapy in rat brain with traumatic injury. Acta Cir. Bras. 2018, 33, 341-353. [CrossRef]

148. Impellizzeri, D.; Campolo, M.; Bruschetta, G.; Crupi, R.; Cordaro, M.; Paterniti, I.; Cuzzocrea, S.; Esposito, E. Traumatic Brain Injury Leads to Development of Parkinson's Disease Related Pathology in Mice. Front. Neurosci. 2016, 10, 458. [CrossRef]

149. Mahmood, A.; Lu, D.; Qu, C.; Goussev, A.; Zhang, Z.G.; Lu, C.; Chopp, M. Treatment of traumatic brain injury in rats with erythropoietin and carbamylated erythropoietin. J. Neurosurg. 2007, 107, 392-397. [CrossRef]

150. Davidson, J.; Cusimano, M.D.; Bendena, W.G. Post-traumatic brain injury: Genetic susceptibility to outcome. Neuroscientist 2015, 21, 424-441. [CrossRef] [PubMed]

151. Finan, J.D.; Udani, S.V.; Patel, V.; Bailes, J.E. The Influence of the Val66Met Polymorphism of Brain-Derived Neurotrophic Factor on Neurological Function after Traumatic Brain Injury. J. Alzheimers Dis. 2018, 65, 1055-1064. [CrossRef] [PubMed] 